\title{
Indium trichloride catalyzed Ferrier rearrangement - facile synthesis of 2,3-unsaturated glycosides
}

\author{
S. B. Boga and K. K. Balasubramanian* \\ Shasun Chemicals \& Drugs Ltd. \\ 60, Velacherry Road \\ Chennai- 600 042, India \\ E-mail:kkbalu@hotmail.com
}

\begin{abstract}
Dedicated to Professor P. T. Narasihman on his $75^{\text {th }}$ birthday
(received 19 Mar 04; accepted 08 Jan 05; published on the web 15 Jan 05)
\end{abstract}

\begin{abstract}
Treatment of tri- $O$-acetyl-D-glucal 1 with various alcohols and phenols in the presence of $\mathrm{InCl}_{3} /$ $\mathrm{CH}_{2} \mathrm{Cl}_{2}$ at ambient temperature furnished the corresponding alkyl and aryl 2,3-unsaturated glycopyranosides in excellent yields in short reaction times and good anomeric selectivity.
\end{abstract}

Keywords: Glycal, glycosides, indium and compounds, Ferrier rearrangement

\section{Introduction}

2,3-Unsaturated glycosides have received wide attention in recent years particularly in the synthesis of several biologically active natural products and also as chiral synthons. Aryl and alkyl 2,3-unsaturatedglucosides are accessible by acid catalyzed nucleophilic substitution with allylic rearrangement of tri- $O$-acetylglucal while it is not that easy to prepare the 2,3-unsaturated galactosides by this route. This reaction, often referred to as the "Ferrier rearrangement", ${ }^{1}$ has found wide application. This reaction continues to receive wide attention and various glycosidation methodologies using it have been extensively reviewed. ${ }^{2}$

The requirement of an acid catalyst to bring about the Ferrier rearrangement precludes its applicability to substrates that are sensitive to acidic conditions. This has led to the development of essentially non-acidic alternative method viz., iodonium reagents (NIS or iodonium dicollidinium perchlorate as promoter) by Fraser-Reid. ${ }^{3}$ Furthermore, Toshima etal $^{4}$ reported a novel method for the glycosidation of glycals under neutral conditions by using a catalytic amount of 2,3-dichloro-5, 6-dicyano- $p$-benzoquinone (DDQ) to furnish 2,3-unsaturated glycosides in high yields. Mereyala etal $^{5}$ described a general and efficient route to 1,6-anhydro2,3-dideoxy- $\beta$-D-erythro-hex-2-enopyranoses via intramolecular Ferrier rearrangement catalyzed 
by $\mathrm{BF}_{3} . \mathrm{Et}_{2} \mathrm{O}$. Toshima et $a l^{6}$ came out with a practical method for the glycosidation of glycals using montmorillonite K-10 (a clay catalyst), an environmentally acceptable, inexpensive catalyst, and we successfully extended this method for the synthesis of 2,3-unsaturated galactosides under microwave irradiation conditions. ${ }^{7}$ Recently Lee etal $^{8}$ reported an efficient and streoselective palladium-catalyzed $O$-glycosylation using glycals. In contrast to the Lewis acid mediated Ferrier rearrangement, the anomeric stereochemistry of this reaction is controlled by the employed ligand.

As part of our ongoing research in carbohydrate chemistry ${ }^{9}$ and our continued interest in Ferrier rearrangement, we have explored the utility of various Lewis acid catalysts to effect this rearrangement. We observed $5 M$ Lithium perchlorate in diethtyl ether (LPDE) is a useful, neutral and mild medium for the synthesis of alkyl and aryl 2,3-unsaturated glucopyranosides and alkyl and aryl 2-deoxy galactopyranosides. An additional feature of interest, from the carbohydrate chemistry point of view, is the reactivity pattern difference between tri- $O$-acetyl-D-galactal 2 as compared to tri-O-acetyl-D-glucal 1 towards alcohols and phenols in (LPDE) medium (Scheme 1). ${ }^{10}$ A plausible mechanism to account for this difference in behavior is that the tri- $O$ acetyglucal, 1, which exists in two different conformations ${ }^{4} \mathrm{H}_{5}$ and ${ }^{5} \mathrm{H}_{4}$ in equilibrium, undergoes Ferrier rearrangement in the ${ }^{5} \mathrm{H}_{4}$ conformation wherein anchimeric assistance is feasible, providing smoothly the 2,3-unsaturated glucosides. However, in the case of tri-Oacetylgalactal, 2, the 3-OAc and 4-OAc are cis to each other and no anchimeric assistance is possible in either of the two conformations. Addition of the alcohol to the enol ether double bond takes a precedence, leading to 2-deoxy galactosides. However, $\mathrm{LiBF}_{4}$ in $\mathrm{CH}_{3} \mathrm{CN}$ (LTAN) was found to be an useful alternative catalyst to $\mathrm{SnCl}_{4}$, ${ }^{1 \mathrm{e}, 10 \mathrm{c}}$ providing a practical method for the synthesis of 2,3-unsaturated alkylglycosides, particularly for 2,3-unsaturated galactopyranosides in good yields. ${ }^{11}$ 

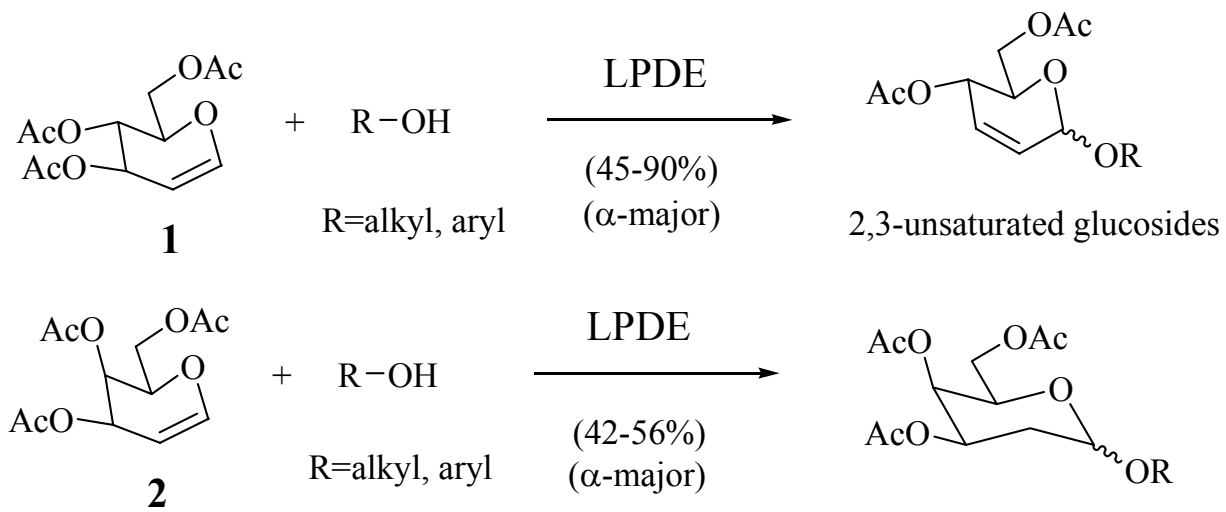

2-deoxy galactosides

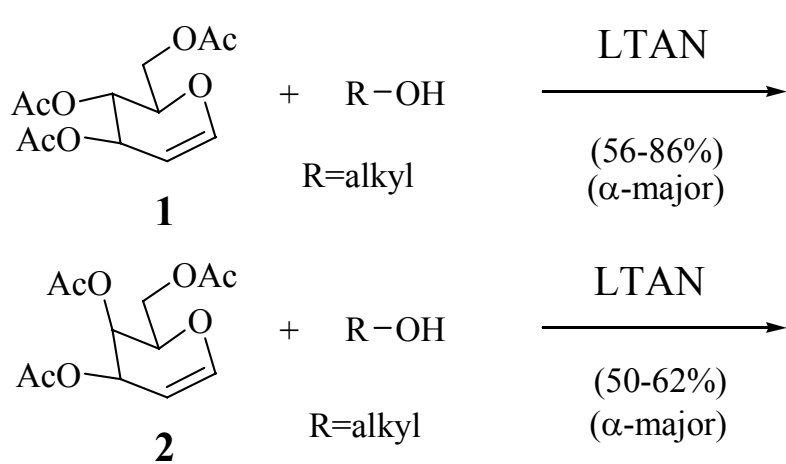<smiles>[R]O[C@H]1C=C[C@@H](OC(C)C)[C@H](COC(C)=O)O1</smiles>

2,3-unsaturated glucosides

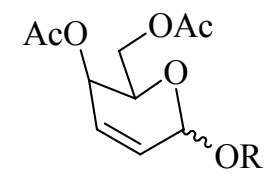

2,3-unsaturated galactosides

\section{Scheme 1}

Indium(III) chloride $\mathrm{InCl}_{3}$, which is a relatively strong Lewis acid, has been used as a catalyst for a wide variety of organic reactions. ${ }^{12}$ However, Indium trichloride has hardly been used in the carbohydrate field. We have found an interesting application for $\mathrm{InCl}_{3}$ as an efficient and versatile catalyst for the expeditious synthesis of alkyl and aryl 2,3-unsaturated glycopyranosides via Ferrier rearrangement. ${ }^{13}$ Recently a few papers have appeared on the $\mathrm{InCl}_{3}$ catalyzed, microwave assisted Ferrier rearrangement of glycals leading to 2,3-unsaturated $O$ - and $C$-glycosides in good to excellent yields. ${ }^{14}$

\section{Results and Discussion}

Synthesis of 2,3-unsaturated alkyl and aryl glycosides using $\mathrm{InCl}_{3}$. When 1 equiv. of tri- $O$ acetyl-D-glucal 1 was treated with 1.2 equiv. of benzyl alcohol and anhydrous $\mathrm{InCl}_{3}$ in $\mathrm{CH}_{2} \mathrm{Cl}_{2}$ for 10 minutes at ambient temperature, a mixture of benzyl 2,3-unsaturated glucopyranosides 3a and $3 \mathrm{~b}$ was obtained in $86 \%$ yield with the $\alpha$-anomer as the major product. The product showed two close moving spots in TLC (almost identical $\mathrm{R}_{f}$ ), corresponding to the $\alpha$ and $\beta$-anomers. The complete assignment of signals in the ${ }^{1} \mathrm{H}$ NMR spectrum was possible based on irradiation studies and the stereochemistry at the anomeric center was established unambiguously as $\alpha$ based 
on our earlier NOE studies ${ }^{9 c}$. When the signal due to H-1 of the alpha anomer was irradiated, there was no significant enhancement in the intensity of the signal due to H-5, and vice versa. Based on the integration values of signals due to anomeric protons ( $\alpha$ and $\beta$ anomeric protons come without overlapping and can be integrated without difficulty) in the ${ }^{1} \mathrm{H} \mathrm{NMR} \mathrm{(400} \mathrm{MHz)}$ spectrum of the mixture, the ratio of the anomers was calculated. Likewise, a few other alcohols (Scheme 2) and phenols (Scheme 3) also underwent the Ferrier rearrangement catalyzed by $\mathrm{InCl}_{3}$ in shorter reaction time furnishing the 2,3-unsaturated glycosides in excellent yields with high selectivity in favor of the $\alpha$-anomer.

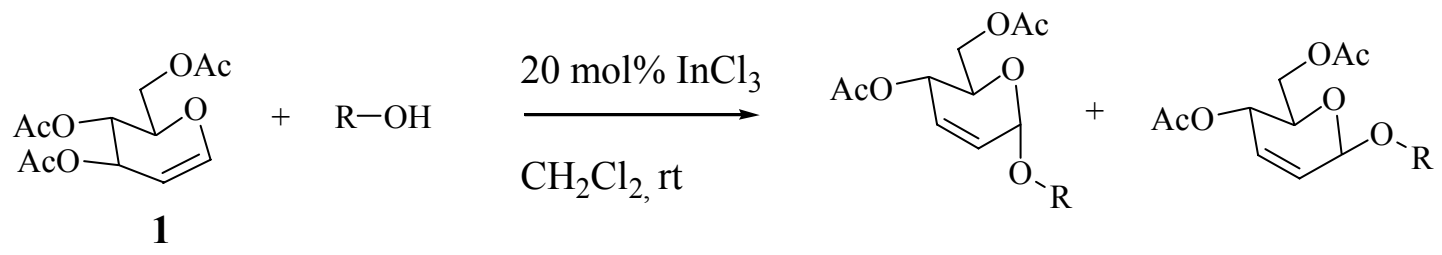

\section{Scheme 2}

\begin{tabular}{cccc}
\hline Alcohol & Product & Yield (\%) & $\alpha: \beta^{*}$ \\
\hline $\mathrm{R}=$ benzyl & $3 \mathrm{a}+3 \mathrm{~b}$ & 86 & $6.3: 1$ \\
$\mathrm{R}=o$-nitrobenzyl & $4 \mathrm{a}+4 \mathrm{~b}$ & 80 & $7: 1$ \\
$\mathrm{R}=o$-iodobenzyl $^{\mathrm{a}}$ & $5 \mathrm{a}+5 \mathrm{~b}$ & 87 & $9: 1$ \\
$\mathrm{R}=$ cyclohexyl $^{\mathrm{b}}$ & $6 \mathrm{a}+6 \mathrm{~b}$ & 90 & $9: 1$ \\
$\mathrm{R}=$ propargyl $^{\mathrm{R}}=$ methyl & $7 \mathrm{a}+6 \mathrm{~b}$ & 90 & $9: 1$ \\
$\mathrm{R}$ & $8 \mathrm{a}+8 \mathrm{~b}$ & 90 & $7: 1$ \\
\hline
\end{tabular}

Time taken for the completion of the reaction is 10 min except ${ }^{\mathrm{a}} 15 \mathrm{~min}$ and ${ }^{\mathrm{b}} 30 \mathrm{~min}$.
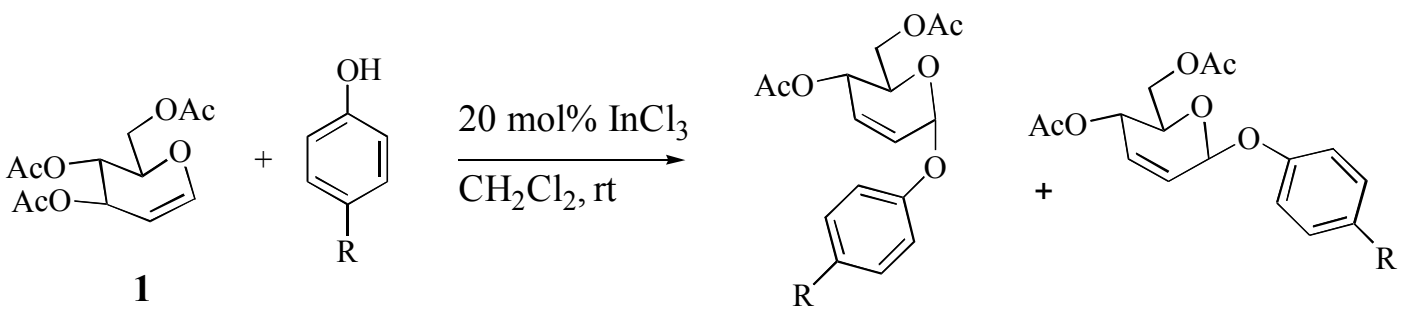

Scheme 3

\begin{tabular}{cccc}
\hline Phenols & Product & Yield (\%) & $\alpha: \beta^{*}$ \\
\hline$p$-methylphenol & $\mathbf{9 a}+\mathbf{9 b}$ & 60 & $8: 1$ \\
$p$-methoxyphenol & $\mathbf{1 0 a}+\mathbf{1 0 b}$ & 65 & $7.5: 1$ \\
- $^{\text {-chlorophenol }}$ & $\mathbf{1 1 a}+\mathbf{1 1 b}$ & 62 & $9: 1$ \\
\hline
\end{tabular}

* Anomeric ratios were determined by ${ }^{1} \mathrm{H}$ and (300 \& $\left.400 \mathrm{MHz}\right)$ spectroscopy

Time taken for the completion of the reaction is 10 min except ${ }^{\mathrm{a}} 15 \mathrm{~min}$. 
This procedure worked equally well for the synthesis of a disaccharide viz. methyl 6-O- [4,6di-O-acetyl-2, 3-dideoxy-D-erythro-hex-2-enopyranosyl]-2,3,4-tri- $O$-methyl- $\alpha$-D-glucopyranoside 13a and $\beta$-anomer 13b (Scheme 4). Thus, reaction of methyl 2,3,4-tri- $O$-methyl- $\alpha$-Dglucopyranoside 12 with 1 in dichloromethane/acetonitrile in the presence of $\mathrm{InCl}_{3}$ led to the known disaccharide ${ }^{6 a}$ 13a and $\mathbf{1 3 b}$ in $80 \%$ yield with $\alpha$-anomer as the major product $(\alpha: \beta=9: 1)$.

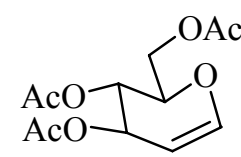

1

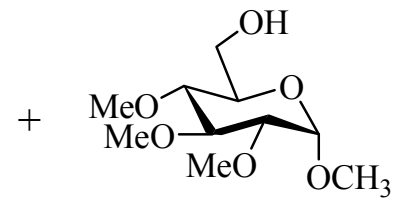

12

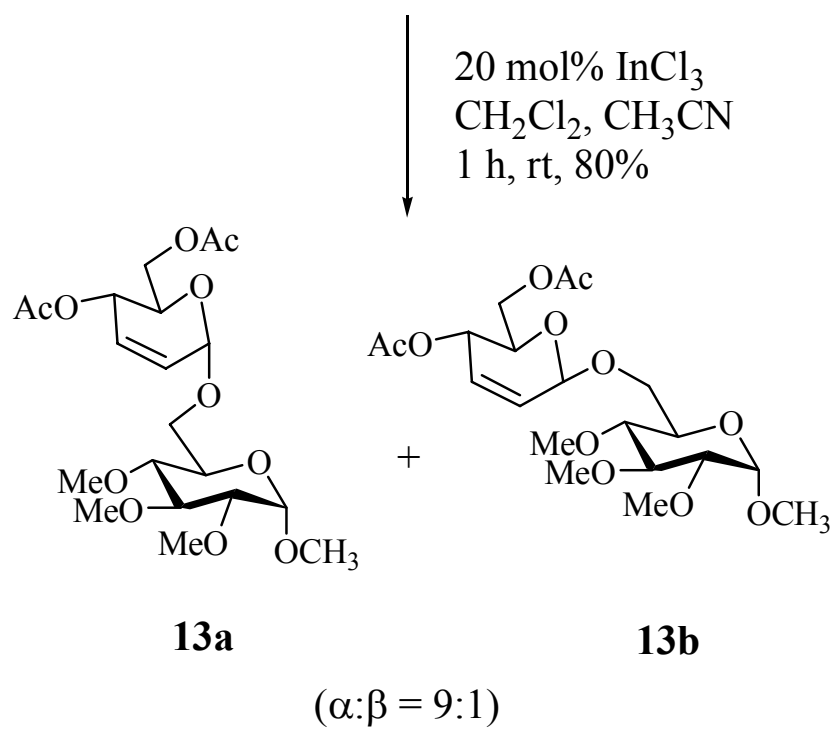

\section{Scheme 4}

\section{Efficacy of various acid catalysts towards the Ferrier rearrangement of 1}

We have examined the efficacy of a few catalysts viz., $\mathrm{LiClO}_{4}, \mathrm{LiBF}_{4}, \mathrm{BF}_{3} . \mathrm{Et}_{2} \mathrm{O}$ and $\mathrm{SnCl}_{4}$ for the Ferrier rearrangement of $\mathbf{1}$ with selected alcohols. We have observed that among all these catalysts, $\mathrm{InCl}_{3}$ is found to be the best (Table 1). 
Table 1. Study of various acid catalysts in the Ferrier rearrangement of $\mathbf{1}$ with alcohols

\begin{tabular}{|c|c|c|c|c|}
\hline Alcohol & Products & Lewis acid catalyst (temp.) & Time & Yield $(\alpha: \beta)^{*}$ \\
\hline \multirow{6}{*}{ Benzyl alcohol } & \multirow{6}{*}{$\mathbf{3 a}+\mathbf{3 b}$} & $\mathrm{LiClO}_{4} / \mathrm{Et}_{2} \mathrm{O}\left(27{ }^{\circ} \mathrm{C}\right)$ & $16 \mathrm{~h}$ & $85 \%(5: 1)$ \\
\hline & & $\mathrm{LiBF}_{4} / \mathrm{CH}_{3} \mathrm{CN}\left(27^{\circ} \mathrm{C}\right)$ & $4 \mathrm{~h}$ & $86 \%(4: 1)$ \\
\hline & & $\mathrm{BF}_{3} / \mathrm{Et}_{2} \mathrm{O}\left(0^{\circ} \mathrm{C}\right.$ to $\left.27{ }^{\circ} \mathrm{C}\right)$ & $45 \min$ & $80 \%(4: 1)$ \\
\hline & & $\mathrm{SnCl}_{4} / \mathrm{CH}_{2} \mathrm{Cl}_{2}\left(0^{\circ} \mathrm{C}\right.$ to $\left.27{ }^{\circ} \mathrm{C}\right)$ & $45 \min$ & $85 \%(4.6: 1)$ \\
\hline & & Montmorillonite K-10 & - & - \\
\hline & & $\mathrm{InCl}_{3} / \mathrm{CH}_{2} \mathrm{Cl}_{2}\left(27^{\circ} \mathrm{C}\right)$ & $10 \min$ & $91 \%(6.3: 1)$ \\
\hline \multirow{6}{*}{ Cyclohexanol } & \multirow{6}{*}{$6 a+6 b$} & $\mathrm{LiClO}_{4} / \mathrm{Et}_{2} \mathrm{O}\left(27^{\circ} \mathrm{C}\right)$ & $18 \mathrm{~h}$ & $90 \%(6: 1)$ \\
\hline & & $\mathrm{LiBF}_{4} / \mathrm{CH}_{3} \mathrm{CN}\left(27{ }^{\circ} \mathrm{C}\right)$ & $4 \mathrm{~h}$ & $86 \%(8: 1)$ \\
\hline & & $\mathrm{BF}_{3} / \mathrm{Et}_{2} \mathrm{O}\left(0^{\circ} \mathrm{C}\right.$ to $\left.27{ }^{\circ} \mathrm{C}\right)$ & $45 \mathrm{~min}$ & $70 \%(9: 1)$ \\
\hline & & $\mathrm{SnCl}_{4} / \mathrm{CH}_{2} \mathrm{Cl}_{2}\left(0^{\circ} \mathrm{C}\right.$ to $\left.27^{\circ} \mathrm{C}\right)$ & $1 \mathrm{~h}$ & $80 \%(6.5: 1)$ \\
\hline & & $\begin{array}{l}\text { Montmorillonite K-10 / } \\
\qquad \mathrm{CH}_{2} \mathrm{Cl}_{2}\end{array}$ & $1 \mathrm{~h}$ & $93 \%(7.3: 1)$ \\
\hline & & $\mathrm{InCl}_{3} / \mathrm{CH}_{2} \mathrm{Cl}_{2}\left(27^{\circ} \mathrm{C}\right)$ & $10 \min$ & $90 \%(9: 1)$ \\
\hline \multirow{6}{*}{$\begin{array}{l}\text { Propargyl } \\
\text { alcohol }\end{array}$} & \multirow{6}{*}{$7 \mathbf{a}+7 \mathbf{b}$} & $\mathrm{LiClO}_{4} / \mathrm{Et}_{2} \mathrm{O}\left(27^{\circ} \mathrm{C}\right)$ & $18 \mathrm{~h}$ & $90 \%(6: 1)$ \\
\hline & & $\mathrm{LiBF}_{4} / \mathrm{CH}_{3} \mathrm{CN}\left(27{ }^{\circ} \mathrm{C}\right)$ & $4 \mathrm{~h}$ & $86 \%(8: 1)$ \\
\hline & & $\mathrm{BF}_{3} / \mathrm{Et}_{2} \mathrm{O}\left(0^{\circ}\right.$ to $\left.27{ }^{\circ} \mathrm{C}\right)$ & $30 \min$ & $82 \%(6.3: 1)$ \\
\hline & & $\mathrm{SnCl}_{4} / \mathrm{CH}_{2} \mathrm{Cl}_{2}\left(0^{\circ} \mathrm{C}\right.$ to $\left.27^{\circ} \mathrm{C}\right)$ & $45 \mathrm{~min}$ & $80 \%(9: 1)$ \\
\hline & & $\begin{array}{l}\text { Montmorillonite K-10 / } \\
\qquad \mathrm{CH}_{2} \mathrm{Cl}_{2}\end{array}$ & $1 \mathrm{~h}$ & $97 \%(6.4: 1)$ \\
\hline & & $\mathrm{InCl}_{3} / \mathrm{CH}_{2} \mathrm{Cl}_{2}\left(27^{\circ} \mathrm{C}\right)$ & $10 \mathrm{~min}$ & $92 \%(9: 1)$ \\
\hline
\end{tabular}

*Anomeric ratios were determined by ${ }^{1} \mathrm{H}$ NMR (200/400 MHz) spectroscopy.

In all the cases studied, the reaction was fastest with $\mathrm{InCl}_{3}$ as compared to other catalysts. It was observed that $\mathrm{InCl}_{3}$ is better than $\mathrm{SnCl}_{4}$. Besides anomeric selectivity; the yield was greatest with $\mathrm{InCl}_{3}$. We have examined a few other catalysts such as $\mathrm{TaCl}_{5}, \mathrm{PsCl}_{3}$, and $\mathrm{LnCl} 3$ also in dichloromethane. However, none of these Lewis acids was found to catalyze the Ferrier rearrangement.

The low yield of 2,3-unsaturated aryl glucopyranosides (Scheme 3) obtained in the case of phenols is due to further ' $\mathrm{O}$ ' to ' $\mathrm{C}$ ' rearrangement catalyzed by $\mathrm{InCl}_{3}$. There is precedence for such a rearrangement from our own earlier work. ${ }^{9 \mathrm{a}}$ 
One-pot synthesis of $\mathbf{C}$-aryl glycosides using $\mathbf{I n C l}_{3}$. When the reaction between tri- $O$-acetyl-Dglucal 1 and $p$-cresol in the presence of anhyd. $\mathrm{InCl}_{3}$ in $\mathrm{CH}_{2} \mathrm{Cl}_{2}$, was carefully monitored by TLC, formation of 4'-methylphenyl 4,6-di-O-acetyl-2, 3-dideoxy- $\alpha$-D-erythro-hex-2enopyranosides 9a and 9b was observed in the initial stages viz. first 10-15 min. Under longer reaction duration, TLC indicated consumption of the $O$-arylglycoside with the simultaneous formation of 2,3-unsaturated- $C$-arylglycosides $\mathbf{1 4 a}$ and $\mathbf{1 4 b}$. It took about $10 \mathrm{~h}$ for completion of this ' $\mathrm{O}$ ' to ' $\mathrm{C}$ ' rearrangement, but the reaction was accompanied by the formation of a substantial amount of an aldehyde product $14 \mathbf{c}$ presumed to be $(5 R, 6 R)-5$-(hydroxy)-4,6-di- $O$-acetyl-hex-2ene-1-al, which was formed probably due to the presence of adventitious moisture (Scheme 5). This problem was overcome by employing $\mathrm{ClCH}_{2} \mathrm{CH}_{2} \mathrm{Cl}$ as the solvent and heating the reaction mixture at $50{ }^{\circ} \mathrm{C}$ for an hour, which led to completion of the reaction without the formation of any side products viz., 14c.

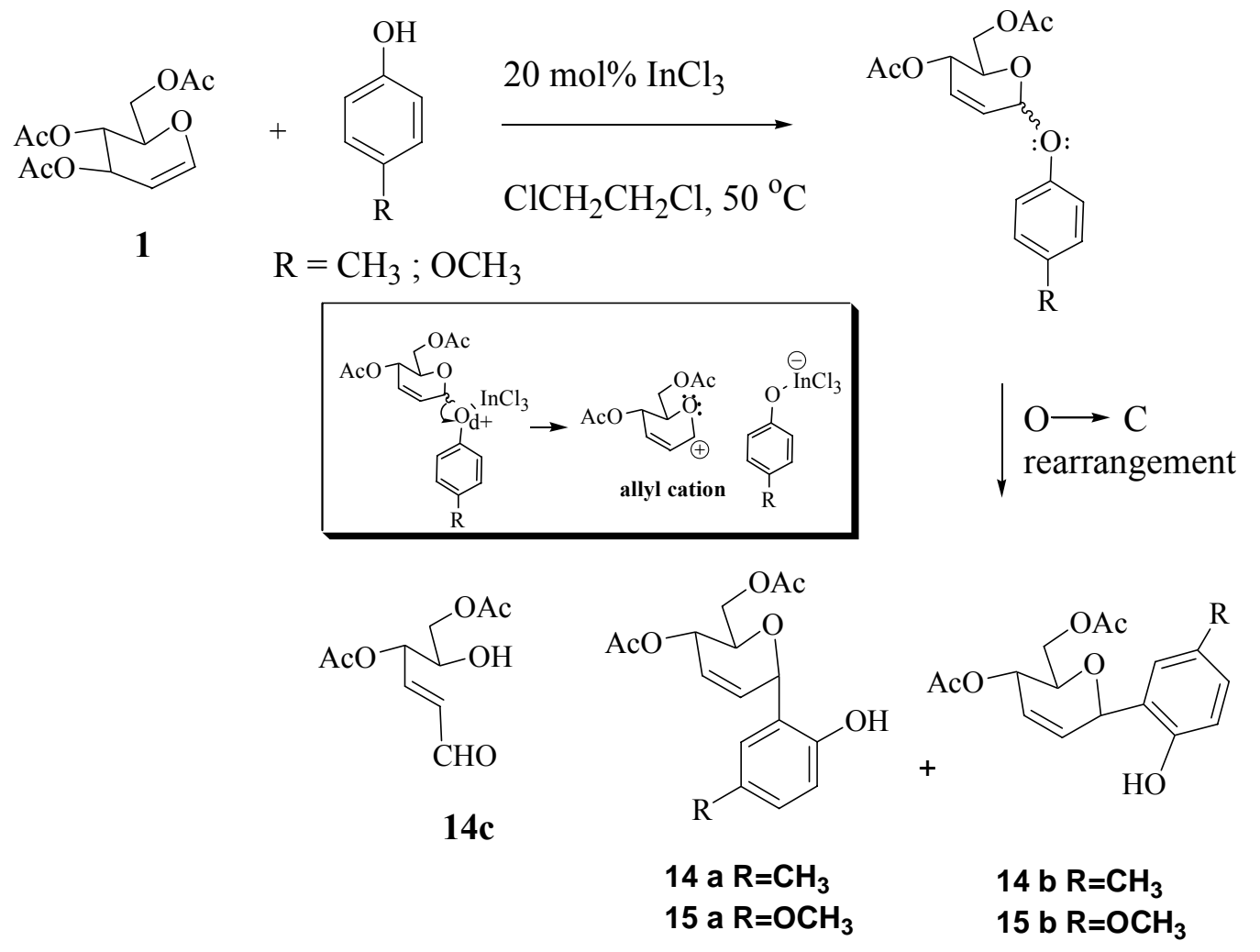

\section{Scheme 5}



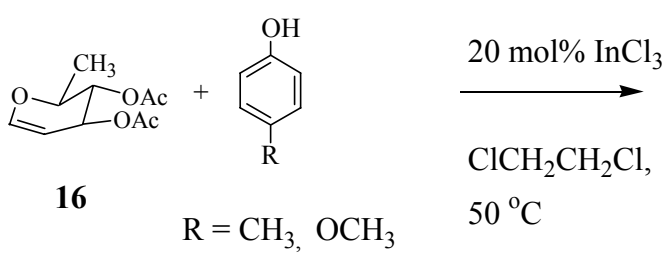
$50{ }^{\circ} \mathrm{C}$
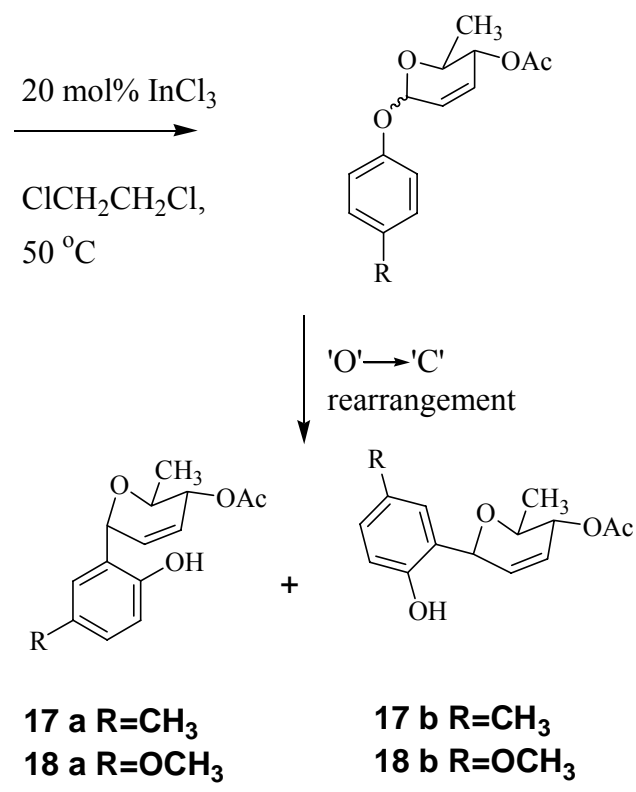

Scheme 6

\begin{tabular}{cccccc}
\hline Glycal & Phenol & Products & Time $(\mathrm{h})$ & Yield (\%) & $\alpha: \beta^{*}$ \\
\hline $\mathbf{1}$ & $\mathrm{R}=\mathrm{CH}_{3}$ & $\mathbf{1 4 a}+\mathbf{1 4 b}$ & 1 & 65 & $37: 63$ \\
& $\mathrm{R}=\mathrm{OCH}_{3}$ & $\mathbf{1 5 a}+\mathbf{1 5 b}$ & 1.5 & 63 & $34:: 66$ \\
\multirow{2}{*}{$\mathbf{1 6}$} & $\mathrm{R}=\mathrm{CH}_{3}$ & $\mathbf{1 7 a}+\mathbf{1 7 b}$ & 2 & 60 & $46: 54$ \\
& $\mathrm{R}=\mathrm{OCH}_{3}$ & $\mathbf{1 8 a}+\mathbf{1 8 b}$ & 2.5 & 65 & $46: 54$ \\
\hline
\end{tabular}

* Anomeric ratios were determined by ${ }^{1} \mathrm{H}$ and $(200 \& 400 \mathrm{MHz})$ spectroscopy.

The intermediate $O$-arylglycoside $9 \mathbf{a}$ and $\mathbf{9 b}$ could be isolated by quenching the reaction mixture with cold $a q . \mathrm{NaOH}$ at the end of $10 \mathrm{~min}$. The ' $\mathrm{O}$ ' to ' $\mathrm{C}$ ' rearrangement pathway for the formation of 14a and 14b was confirmed by taking the pure $O$-arylglycosides $9 \mathbf{a}$ and $\mathbf{9 b}$ and subjecting them to the action of $\mathrm{InCl}_{3}$ in dichloroethane which led to the $C$-arylglycoside 14a and 14b. This is an indication of a cleavage-recombination mechanism involving the intermediacy of highly stabilized allyl cation. It is worth mentioning that products of allylic attack at C-3 are not observed which is in agreement with the high electrophilic nature of the anomeric center in these glycals. While this method provides a convenient one-pot synthesis of $C$-aryl glycosides and also a rapid entry to 2,3-unsaturated- $C$-aryl glucopyranosides, it is not diastereoselective (Scheme 5). The reaction was successfully tested on $p$-methoxyphenol, which afforded a mixture of corresponding $C$-arylglycoside $\mathbf{1 5 a}$ and $\mathbf{1 5 b}$ in $63 \%$ yield albeit with poor anomeric selectivity. The diastereoselectivity observed however, was comparable to that reported with $\mathrm{BF}_{3} \cdot \mathrm{Et}_{2} \mathrm{O}$ as catalyst $^{9 \mathrm{a}}$.

The reaction underwent by 3,4-di- $O$-acetyl- $L$-rhamnal $\mathbf{1 6}$ also, which furnished the corresponding 2,3-unsaturated $C$-arylrhamnosides in moderate yields but without any significant anomeric selectivity.17-18 (Scheme 6). From this limited data, it appears that the presence of the substituent at C-6 does not have any influence on the anomeric selectivity in this reaction. 
Strangely, under identical conditions tri- $O$-acetyl-D-galactal 2 yielded a complex mixture of products. All new compounds were thoroughly characterized by spectral means.

It should be emphasized that indium chloride has to be extremely anhydrous to effect the Ferrier rearrangement of $\mathbf{1}$ and $\mathbf{1 6}$ with various aglycons. Use of hydrated indium trichloride $\left(\mathrm{InCl}_{3} 3 \mathrm{H}_{2} \mathrm{O}\right)$ on 1 led to the formation of substantial amount of $\mathbf{1 4 c}$ even in the presence of aglycon. Since anhydrous $\mathrm{InCl}_{3}$ was found to be an efficient catalyst for Ferrier rearrangement it appeared worthwhile to examine its behavior towards free glycals. In the event, it led to a facile transformation affording the 2-(D-glycero-1', 2'-dihydroxyethyl) furan 21, a very useful and important chiral intermediate in organic synthesis. ${ }^{18}$ Treatment of unprotected D-glucal 19 or Dgalactal 20 with $\mathrm{InCl}_{3} \cdot 3 \mathrm{H}_{2} \mathrm{O}(10 \mathrm{~mol} \%)$ in acetonitrile at ambient temperature furnished 2-(Dglycero-1,2-dihydroxyethyl) furan 21, an optically active furan diol in 82\% yield (Scheme 7).

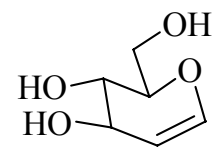

19

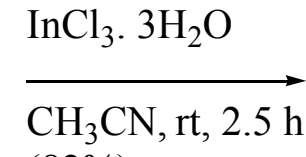

$(82 \%)$

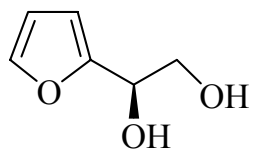

21

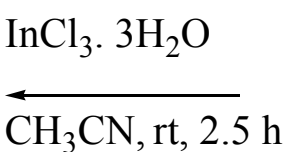

$(82 \%)$

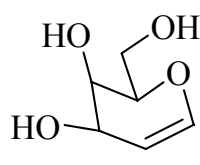

20

Scheme 7

\section{Conclusions}

1) Our study has revealed that anhydrous $\mathrm{InCl}_{3}$ is the best catalyst among all the catalysts $\left(\mathrm{LiClO}_{4}, \mathrm{LiBF}_{4}, \mathrm{BF}_{3} \mathrm{Et}_{2} \mathrm{O}, \mathrm{SnCl}_{4}\right.$, and Montmorillonite $\mathrm{K}-10$ for the Ferrier rearrangement of tri$O$-acetyl-D-glucal $\mathbf{1}$. The reaction conditions are mild and reaction time is also relatively short. The reaction proceeded with good anomeric selectivity, furnishing high isolated yields of the products. The reaction is amenable for scale-up. The quantity of the nucleophile used for glycosylation by this method is only 1.2 equiv. as compared to 10 equiv. used in the conventional thermal Ferrier rearrangement. The medium is compatible with the ester group, thus avoiding the attendant problem of transesterification. The reaction has been extended to Lrhamnal also, but in the case of tri- $O$-acetyl-D-galactal, the reaction was not clean and led to a mixture of products.

2) A tandem Ferrier rearrangement and ' $O$ ' to ' $C$ ' rearrangement of tri- $O$-acetyl-D-glucal and diO-acetyl-L-rhamnal with phenols to form the 2,3-unsaturated $C$-arylglucosides and $C$ arylrhamnosides respectively was achieved using anhyd. $\mathrm{InCl}_{3} / \mathrm{ClCH}_{2} \mathrm{CH}_{2} \mathrm{Cl}$ at $50{ }^{\circ} \mathrm{C}$. 


\section{Experimental Section}

Tri- $O$-acetyl-D-glucal 1, tri- $O$-acetyl-D-galactal 2 and 3,4-di- $O$-acetyl-L-rhamnal 16 were prepared according to the literature procedures. ${ }^{15}$

General Procedures. To a mixture of tri- $O$-acetyl-D-glucal $1(1 \mathrm{mmol})$ and the aglycone $(1.1 \mathrm{mmol})$, was added anhydrous $\mathrm{InCl}_{3}(0.2 \mathrm{mmol} ; 20 \mathrm{~mol} \%)$ in dry $\mathrm{CH}_{2} \mathrm{Cl}_{2}(1-2 \mathrm{~mL})$ (For $C$ aryl glycosides, $\mathrm{ClCH}_{2} \mathrm{CH}_{2} \mathrm{Cl}$ was used as the solvent and heated the reaction mixture at $50{ }^{\circ} \mathrm{C}$ for the required time) at ambient temperature. The contents were stirred for the required time and the reaction monitored by TLC. The reaction mixture was quenched by the addition of aqueous sodium hydrogen carbonate $(10 \%, 25 \mathrm{~mL})$, extracted with dichloromethane $(3 \times 25 \mathrm{~mL})$, dried over anhydrous sodium sulphate, filtered and concentrated. The residue was purified by flash column chromatography on silica gel to obtain the products using hexane: EtOAc as eluents.

The product showed two close moving spots in TLC (almost identical $R_{f}$ ), corresponding to the $\alpha$ and $\beta$-anomers. The mixture of anomers was not separated but characterized as such by HRMS and NMR spectroscopy. Based on the integration values of signals due to anomeric protons in the ${ }^{1} \mathrm{H}$ NMR spectrum of mixture, the ratio of the anomers was calculated.

Benzyl 4,6-di-O-acetyl-2,3-dideoxy - $\alpha$-D-erythro-hex-2-enopyranoside (3a) and $\beta$-anomer (3b). ${ }^{16}$ Nature: Viscous liquid. $R_{f}: 0.5$ (Hexane : EtOAc $\left.=8: 2\right)$. IR $\left(\mathrm{CHCl}_{3}\right) v\left(\mathrm{~cm}^{-1}\right): 2944$, 1734, 1644, 1599, 1446, 1382, 1260, 1193; ${ }^{1} \mathrm{H}$ NMR (300 MHz) $\delta(\mathrm{ppm}): 2.07(\mathrm{~s}, 3 \mathrm{H},-$ $\left.\mathrm{OCOCH}_{3}\right), 2.09\left(\mathrm{~s}, 3 \mathrm{H},-\mathrm{OCOCH}_{3}\right) 4.09-4.31(\mathrm{~m}, 3 \mathrm{H}, \mathrm{H}-5, \mathrm{H}-6 \mathrm{a}, \mathrm{H}-6 \mathrm{~b}), 4.59(\mathrm{~d}, \mathrm{~J}=11.65 \mathrm{~Hz}, 1 \mathrm{H}$, $\mathrm{A}$ of $\left.\mathrm{AB}, \mathrm{PhCH}_{\mathrm{A}}\right), 4.80(\mathrm{~d}, \mathrm{~J}=11.65 \mathrm{~Hz}, 1 \mathrm{H}, \mathrm{B}$ of $\mathrm{AB} \mathrm{PhCH}$ ) $5.13(\mathrm{bs}, 1 \mathrm{H}, \mathrm{H}-1$ of $\alpha), 5.20(\mathrm{bs}$, $\mathrm{H}-1$ of $\beta), 5.33\left(\mathrm{~d}, \mathrm{~J}_{4,5}=10.1 \mathrm{~Hz}, 1 \mathrm{H}, \mathrm{H}-4\right), 5.83-5.88(\mathrm{~m}, 2 \mathrm{H}, \mathrm{H}-2, \mathrm{H}-3), 7.28-7.36(\mathrm{~m}, 5 \mathrm{H}, \mathrm{Ar}-\mathrm{H})$.

${ }^{13} \mathrm{C}$ NMR $(75 \mathrm{MHz}) \delta(\mathrm{ppm}): 20.70\left(\mathrm{q},-\mathrm{OCOCH}_{3}\right), 20.86\left(\mathrm{q},-\mathrm{OCOCH}_{3}\right), 62.81(\mathrm{t}, \mathrm{C}-6), 65.16(\mathrm{~d}$, C-5), 66.94(d, C-4), 70.17(t, $\left.-\mathrm{OCH}_{2} \mathrm{Ar}\right), 93.52(\mathrm{~d}, \mathrm{C}-1$ of $\alpha$ ), 93.61(d, C-1 of $\beta$ ), 127.65(d, Ar$\mathrm{CH}), 127.84(\mathrm{~d}, \mathrm{Ar}-\mathrm{CH}), 127.78(\mathrm{~d}, \mathrm{C}-2$ ) $), 128.37(\mathrm{~d}, \mathrm{C}-3), 137.46(\mathrm{~s}, \mathrm{Ar}-\mathrm{C}), 170.20\left(\mathrm{~s},-\mathrm{OCOCH}_{3}\right)$, 170.70(s, $\left.-\mathrm{OCOCH}_{3}\right) . \mathrm{MS}(\mathrm{m} / \mathrm{z}): 380,278,242,218,213,200,176,153,111,91$; HRMS: Observed 261.129595 $\left(\mathrm{M}^{+}-\mathrm{OCOCH}_{3}\right)$ Calculated 261.13269 for $\mathrm{C}_{15} \mathrm{H}_{17} \mathrm{O}_{4}$

2'-Nitrobenzyl 4,6-di-O-acetyl-2,3-dideoxy- $\alpha$-D-erythro-hex-2-enopyranoside (4a) and $\beta$ anomer (4b). Nature: Yellow gummy solid. $\mathrm{R}_{f}: 0.6$ (Hexane : EtOAc $\left.=7: 3\right)$. IR $\left(\mathrm{CHCl}_{3}\right)$ $v\left(\mathrm{~cm}^{-1}\right): 3008,2992,1737,1542,1526,1456,1434,1360,1340,1257,1145,1046,966,934$, 834, 649, 633; ${ }^{1} \mathrm{H}$ NMR (400 MHz) $\delta$ (ppm): 2.07 (s, 3H, - $\mathrm{OCOCH}_{3}$ ), 2.09 (s, 3H, - $\mathrm{OCOCH}_{3}$ ), 4.11-4.29(m, 3H, H-5, H-6a, H-6b), 4.97(d, J = 14.3Hz, $1 \mathrm{H}, \mathrm{A}$ of $\left.\mathrm{AB}, \mathrm{PhCH}_{\mathrm{A}}\right), 5.20(\mathrm{~d}, \mathrm{~J}=$ $14.3 \mathrm{~Hz}, 1 \mathrm{H}, \mathrm{B}$ of $\left.\mathrm{AB}, \mathrm{PhCH}_{\mathrm{B}}\right), 5.19(\mathrm{bs}, 1 \mathrm{H}, \mathrm{H}-1), 5.29(\mathrm{~d}, \mathrm{~J}=8.3 \mathrm{~Hz}, 1 \mathrm{H}, \mathrm{H}-4), 5.91-5.93(\mathrm{~m}, 2 \mathrm{H}$, $\mathrm{H}-2, \mathrm{H}-3), 7.45(\mathrm{t}, \mathrm{J}=7.23 \mathrm{~Hz}, 1 \mathrm{H}, \mathrm{Ar}-\mathrm{H}), 7.63-7.76(\mathrm{~m}, 2 \mathrm{H}, \mathrm{Ar}-\mathrm{H}), 8.08(\mathrm{~d}, \mathrm{~J}=7.69 \mathrm{~Hz}, 1 \mathrm{H}, \mathrm{Ar}-\mathrm{H})$. ${ }^{13} \mathrm{C}$ NMR $(100 \mathrm{MHz}) \delta(\mathrm{ppm}): 20.73\left(\mathrm{q},-\mathrm{OCOCH}_{3}\right), 20.96\left(\mathrm{q},-\mathrm{OCOCH}_{3}\right), 62.81(\mathrm{t}, \mathrm{C}-6), 65.19(\mathrm{~d}$, C-5), 67.12(t, - $\left.-\mathrm{OCH}_{2}-\mathrm{Ar}\right), 67.27(\mathrm{~d}, \mathrm{C}-4), 94.41(\mathrm{~d}, \mathrm{C}-1), 124.71(\mathrm{~d},-\mathrm{ArCH}), 127.20(\mathrm{~d}, \mathrm{Ar}-\mathrm{CH})$, 128.38(d, C-2), 129.15(d, Ar-CH), 129.73(d, C-3), 133.60(d, Ar-CH), 134.07(s, Ar-C), 147.52(s, $\mathrm{Ar}-\mathrm{C}), 170.32\left(\mathrm{~s},-\mathrm{OCOCH}_{3}\right), 170.90\left(\mathrm{~s},-\mathrm{OCOCH}_{3}\right) . \mathrm{MS}(\mathrm{m} / \mathrm{z}): 306\left(\mathrm{M}^{+}-2 \times \mathrm{OAc}\right)$, , 263, 221, 
213, 153, 136, 111, 78, 65, 51 HRMS: Observed 306.1250735( $\mathrm{M}^{+}-2$ x OAc) Calculated 306.127765 for $\mathrm{C}_{15} \mathrm{H}_{16} \mathrm{O}_{6} \mathrm{~N}$

2'-Iodobenzyl 4,6-di-O-acetyl-2,3-dideoxy- $\alpha$-D-erythro-hex-2-enopyranoside (5a) and $\beta$ anomer (5b). Nature: Viscous liquid. $R_{f}: 0.6$ (hexane : EtOAc $\left.=7: 3\right)$. IR $\left(\mathrm{CHCl}_{3}\right) v\left(\mathrm{~cm}^{-1}\right)$ : 2948, 1740, 16539, 1433, 1408, 1363, 1260, 1260, 1142, 1097, 1046, 963, 934; ${ }^{1} \mathrm{H}$ NMR (300 $\mathrm{MHz}) \delta(\mathrm{ppm}): 2.08\left(\mathrm{~s}, 3 \mathrm{H},-\mathrm{OCOCH}_{3}\right), 2.10\left(\mathrm{~s}, 3 \mathrm{H},-\mathrm{OCOCH}_{3}\right), 4.14-4.30(\mathrm{~m}, 3 \mathrm{H}, \mathrm{H}-5, \mathrm{H}-6 \mathrm{a}$, $\mathrm{H}-6 \mathrm{~b}), 4.56\left(\mathrm{~d}, \mathrm{~J}=12.53 \mathrm{~Hz}, \mathrm{~A}\right.$ of $\left.\mathrm{AB}, \mathrm{PhCH}_{\mathrm{A}}\right), 4.83\left(\mathrm{~d}, \mathrm{~B}\right.$ of $\left.\mathrm{AB}, 1 \mathrm{H}, \mathrm{J}=12.53 \mathrm{~Hz}, \mathrm{PhCH}_{\mathrm{B}}\right)$, $5.20\left(\mathrm{bs}, 1 \mathrm{H}, \mathrm{H}-1\right.$ of $\alpha$ ) 5.28(bs, $1 \mathrm{H}, \mathrm{H}-1$ of $\beta$ ), 5.33(d, J $\left.\mathrm{J}_{4,5}=9.24 \mathrm{~Hz}, \mathrm{H}-4\right), 5.92(\mathrm{bs}, 2 \mathrm{H}, \mathrm{H}-2, \mathrm{H}-3$ of $\alpha), 6.04(\mathrm{bs}, 2 \mathrm{H}, \mathrm{H}-2, \mathrm{H}-3$ of $\beta), 6.99(\mathrm{t}, \mathrm{J}=7.56 \mathrm{~Hz}, 1 \mathrm{H}, \mathrm{Ar}-\mathrm{H}), 7.26-7.45(\mathrm{~m}, 2 \mathrm{H}, \mathrm{Ar}-\mathrm{H})$, 7.84(d, J $=7.86 \mathrm{~Hz}, 1 \mathrm{H}, \mathrm{Ar}-\mathrm{H}) .{ }^{13} \mathrm{C} \mathrm{NMR}(75 \mathrm{MHz}) \delta(\mathrm{ppm}): 20.86\left(\mathrm{q},-\mathrm{OCOCH}_{3}\right), 20.96(\mathrm{q},-$ $\left.\mathrm{OCOCH}_{3}\right), 62.86(\mathrm{t}, \mathrm{C}-6), 65.20(\mathrm{~d}, \mathrm{C}-5), 67.18(\mathrm{~d}, \mathrm{C}-4), 74.26\left(\mathrm{t},-\mathrm{OCH}_{2}-\mathrm{Ar}\right), 94.20(\mathrm{~d}, \mathrm{C}-1$ of $\alpha)$, 98.15(d, C-1 of $\beta), 98.15(\mathrm{~s}, \mathrm{Ar}-\mathrm{CI}), 127.46(\mathrm{~d}, \mathrm{C}-2), 128.26(\mathrm{~d}, \mathrm{Ar}-\mathrm{CH}), 129.30(\mathrm{~d}, \mathrm{Ar}-\mathrm{CH})$, 129.46(d, C-3), 139.29(s, Ar-C), 139.85(s, Ar-C), 170.26(s, $\left.-\mathrm{OCOCH}_{3}\right), 170.80\left(\mathrm{~s},-\mathrm{OCOCH}_{3}\right)$. HRMS: Observed 446.0195548; Calculated 446.022462 for $\mathrm{C}_{17} \mathrm{H}_{19} \mathrm{O}_{6} \mathrm{I}$

Cycohexyl 4,6-di-O-acetyl-2,3-dideoxy- $\alpha$-D-erythro-hex-2-enopyranoside (6a) and $\beta$-anomer (6b). Nature: Viscous liquid. $R_{f}: 0.7$ (hexane : EtOAc $=7: 3$ ). IR $\left(\mathrm{CHCl}_{3}\right) v\left(\mathrm{~cm}^{-1}\right): 2949,1738$, 1640, 1598, 1439, 1380, 1266, 1182, 1122, 1015; ${ }^{1} \mathrm{H}$ NMR $(300 \mathrm{MHz}) \delta(\mathrm{ppm}): 1.05-1.55(\mathrm{~m}$, $6 \mathrm{H}), 1.62-1.75(\mathrm{~m}, 2 \mathrm{H}), 1.83-1.98(\mathrm{~m}, 2 \mathrm{H}), 2.09\left(\mathrm{~s}, 3 \mathrm{H},-\mathrm{OCOCH}_{3}\right), 2.09\left(\mathrm{~s}, 3 \mathrm{H},-\mathrm{OCOCH}_{3}\right)$, 3.58-3.69(m, 1H, - OCH $\left.\left(\mathrm{CH}_{2}\right)_{5}\right)$, 4.05-4.33(m, 3H, H-5, H-6a, H-6b), 5.16(bs, 1H, H-1), 5.29(d, J $=8.28 \mathrm{~Hz}, 1 \mathrm{H}, \mathrm{H}-4), 5.77-5.94(\mathrm{~m}, 2 \mathrm{H}, \mathrm{H}-2, \mathrm{H}-3) .{ }^{13} \mathrm{C} \mathrm{NMR}(75 \mathrm{MHz}) \delta(\mathrm{ppm}): 20.69(\mathrm{q},-$ $\left.\mathrm{OCOCH}_{3}\right), 20.91\left(\mathrm{q},-\mathrm{OCOCH}_{3}\right), 24.12(\mathrm{t}), 24.34(\mathrm{t}), 25.53(\mathrm{t}), 32.10(\mathrm{t}), 33.73(\mathrm{t}), 63.14(\mathrm{t}, \mathrm{C}-6)$, 65.43(d, C-5), 66.74(d, C-4), 76.68(d, $\left.-\mathrm{OCH}\left(\mathrm{CH}_{2}\right)_{5}\right), 92.76(\mathrm{~d}, \mathrm{C}-1), 128.53(\mathrm{~d}, \mathrm{C}-2), 128.70(\mathrm{~d}, \mathrm{C}-$ 3), 170.28( (s, $\left.-\mathrm{OCOCH}_{3}\right), 170.72\left(\mathrm{~s},-\mathrm{COCH}_{3}\right)$.

HRMS: Observed 312.159426; Calculated 312.15729 for $\mathrm{C}_{16} \mathrm{H}_{24} \mathrm{O}_{6}$

Propargyl 4,6-di-O-acetyl-2,3-dideoxy- $\alpha$-D-erythro-hex-2-enopyranoside (7a) and $\beta$-anomer (7b). ${ }^{17}$ Nature: Viscous liquid. $R_{f}: 0.7$ (hexane : EtOAc $\left.=7: 3\right)$. IR $\left(\mathrm{CHCl}_{3}\right) v\left(\mathrm{~cm}^{-1}\right): 2951,2112$, 1740, 1641, 1601, 1, 1380, 1266, 1182, 1122, 1015; ${ }^{1} \mathrm{H}$ NMR (400 MHz) $\delta(\mathrm{ppm}): 2.08$ (s, 3H, $\left.\mathrm{OCOCH}_{3}\right), 2.10\left(\mathrm{~s}, 3 \mathrm{H},-\mathrm{OCOCH}_{3}\right), 2.47\left(\mathrm{t}, \mathrm{J}=2.42 \mathrm{~Hz}, 1 \mathrm{H},-\mathrm{OCH}_{2}-\mathrm{C} \equiv \mathrm{CH}\right), 3.8-4.24(\mathrm{~m}, 3 \mathrm{H}, \mathrm{H}-5$, $\mathrm{H}-6 \mathrm{a}, \mathrm{H}-6 \mathrm{~b}), 4.31\left(\mathrm{~d}, \mathrm{~J}=2.44 \mathrm{~Hz}, 2 \mathrm{H},-\mathrm{OCH}_{2}-\mathrm{C} \equiv \mathrm{CH}\right), 5.24(\mathrm{bs}, 1 \mathrm{H}, \mathrm{H}-1), .5 .34\left(\mathrm{~d}, \mathrm{~J}_{4,5}=9.57 \mathrm{~Hz}\right.$, $\mathrm{H}-4), 5.80-5.95(\mathrm{~m}, 2 \mathrm{H}, \mathrm{H}-2, \mathrm{H}-3) .{ }^{13} \mathrm{C} \mathrm{NMR}(100 \mathrm{MHz}) \delta(\mathrm{ppm}): 20.68\left(\mathrm{q},-\mathrm{OCOCH}_{3}\right), 20.84(\mathrm{q},-$ $\left.\mathrm{OCOCH}_{3}\right), 54.98\left(\mathrm{~d},-\mathrm{OCH}_{2}-\mathrm{C} \equiv \mathrm{CH}\right), 62.71\left((\mathrm{t}, \mathrm{C}-6), 65.10\left(\mathrm{t},-\mathrm{OCH}_{2}-\mathrm{C} \equiv \mathrm{CH}\right), 67.14(\mathrm{~d}, \mathrm{C}-5)\right.$, 74.75(d, C-4), 79.03(s, $\left.-\mathrm{OCH}_{2}-\mathrm{C} \equiv \mathrm{CH}\right), 92.70(\mathrm{~d}, \mathrm{C}-1$ of $\alpha), 92.50(\mathrm{~d}, \mathrm{C}-1$ of $\beta), 127.18(\mathrm{~d}, \mathrm{C}-2)$, 129.69(d, C-3), 170.14(s, $\left.-\mathrm{OCOCH}_{3}\right), 170.65\left(\mathrm{~s},-\mathrm{OCOCH}_{3}\right) . \mathrm{MS}(\mathrm{m} / \mathrm{z}): 268,230,213,171,153$, $11,83,55$

HRMS: Observed 268.09669; Calculated 268.09469 for $\mathrm{C}_{13} \mathrm{H}_{16} \mathrm{O}_{6}$

Methyl 4,6-di-O-acetyl-2,3-dideoxy- $\alpha$-D-erythro-hex-2-enopyranoside (8a) and $\beta$-anomer (8b). ${ }^{1 \mathrm{c}}$ Nature: Viscous liquid. $R_{f}: 0.6$ (hexane : EtOAc $\left.=7: 3\right) . \mathrm{IR}\left(\mathrm{CHCl}_{3}\right) v\left(\mathrm{~cm}^{-1}\right): 2928,2816$, $1734,1593,1449,1369,1264,1180,1136,1107,1065,1014,963,905 ;{ }^{1} \mathrm{H}$ NMR $(200 \mathrm{MHz}) \delta$ (ppm): 2.08 (s, 6H, 2 x - $\mathrm{OCOCH}_{3}$ of $\alpha$ ), 2.09 (s, 6H, 2 x -OCOCH 3 of $\beta$ ), 3.45(s, 3H, $\mathrm{OCH}_{3}$ of $\alpha), 3.46\left(\mathrm{~s}, 3 \mathrm{H}, \mathrm{OCH}_{3}\right.$ of $\left.\beta\right), 3.99-4.31(\mathrm{~m}, 3 \mathrm{H}, \mathrm{H}-5, \mathrm{H}-6 \mathrm{a}, \mathrm{H}-6 \mathrm{~b}), 4.93(\mathrm{bs}, 1 \mathrm{H}, \mathrm{H}-1$ of $\alpha), 5.04(\mathrm{~d}$, 
$\mathrm{J}_{1,2}=1.09 \mathrm{~Hz}, 1 \mathrm{H}, \mathrm{H}-1$ of $\beta$ ), 5.16-5.20(m, $1 \mathrm{H}, \mathrm{H}-4$ of $\beta$ ), $5.31\left(\mathrm{dd}, \mathrm{J}_{4,5}=9.67 \mathrm{~Hz}, \mathrm{~J}_{3,4}=1.09 \mathrm{~Hz}\right.$, $1 \mathrm{H}, \mathrm{H}-4$ of $\alpha), 5.79-5.87(\mathrm{~m}, 2 \mathrm{H}, \mathrm{H}-2, \mathrm{H}-3$ of $\alpha), 5.90-6.03(\mathrm{~m}, 2 \mathrm{H}, \mathrm{H}-2, \mathrm{H}-3$ of $\beta) .{ }^{13} \mathrm{C}$ NMR $(50 \mathrm{MHz}) \delta(\mathrm{ppm}): 20.59\left(\mathrm{q},-\mathrm{OCOCH}_{3}\right), 20.76\left(\mathrm{q},-\mathrm{OCOCH}_{3}\right), 55.11\left(\mathrm{q}, \mathrm{OCH}_{3}\right.$ of $\left.\beta\right), 55.73(\mathrm{q}$, $\mathrm{OCH}_{3}$ of $\left.\alpha\right), 63.20(\mathrm{t}, \mathrm{C}-6), 65.08(\mathrm{~d}, \mathrm{C}-5), 66.69(\mathrm{~d}, \mathrm{C}-4), 95.23(\mathrm{~d}, \mathrm{C}-1$ of $\alpha), 95.81(\mathrm{~d}, \mathrm{C}-1$ of $\beta)$, 127.51(d, C-2), 129.04(d, C-3), 170.06(s, $\left.-\mathrm{OCOCH}_{3}\right), 170.55\left(\mathrm{~d},-\mathrm{OCOCH}_{3}\right)$. HRMS: Observed 244.15920; Calculated 244.12469 for $\mathrm{C}_{11} \mathrm{H}_{16} \mathrm{O}_{6}$

4'-Methylphenyl 4,6-di-O-acetyl-2,3-dideoxy- $\alpha$-D-erythro-hex-2-enopyranoside (9a) and $\beta$ anomer (9b). ${ }^{1 \mathrm{a}, 9 \mathrm{c}}$ Nature: Gummy solid. $R_{f}: 0.7$ (hexane : EtOAc $=7: 3$ ). IR $\left(\mathrm{CHCl}_{3}\right) v\left(\mathrm{~cm}^{-1}\right)$ : 2948, 1738, 1602, 1446, 1376, 1272, 1182, 1126; ${ }^{1} \mathrm{H}$ NMR (400 MHz) $\delta(\mathrm{ppm}): 1.88(\mathrm{~s}, 3 \mathrm{H},-$ $\mathrm{OCOCH}_{3}$, of $\left.\alpha\right), 2.10\left(\mathrm{~s}, 3 \mathrm{H},-\mathrm{OCOCH}_{3}\right.$, of $\left.\alpha\right), 2.00\left(\mathrm{~s}, 3 \mathrm{H},-\mathrm{OCOCH}_{3}\right.$ of $\left.\beta\right), 2.10(\mathrm{~s}, 3 \mathrm{H},-$ $\mathrm{OCOCH}_{3}$ of $\left.\beta\right), 2.29\left(\mathrm{~s}, 3 \mathrm{H}, \mathrm{ArCH}_{3}\right), 4.06-4.39\left(\mathrm{~m}, 3 \mathrm{H}, \mathrm{H}-5, \mathrm{H}-6_{\mathrm{a}}, \mathrm{H}-6_{\mathrm{b}}\right), 5.16(\mathrm{bs}, 1 \mathrm{H}, \mathrm{H}-4$ of $\beta)$, $5.38\left(\mathrm{~d}, \mathrm{~J}_{4,5}=9.54 \mathrm{~Hz}, \mathrm{H}-4\right.$ of $\alpha$ ), 5.63(bs, $1 \mathrm{H}, \mathrm{H}-1$ of $\alpha$ ), 5.75(bs, $1 \mathrm{H}, \mathrm{H}-1$ of $\left.\beta\right), 6.00(\mathrm{bs}, 2 \mathrm{H}, \mathrm{H}-2$ and $\mathrm{H}-3$ of $\alpha), 6.13(\mathrm{bs}, 2 \mathrm{H}, \mathrm{H}-2, \mathrm{H}-3$ of $\beta), 7.01\left(\mathrm{~d}, 2 \mathrm{H}, \mathrm{J}=8.48 \mathrm{~Hz}, \mathrm{Ar}-\mathrm{H}, \mathrm{H}_{\mathrm{A}}, \mathrm{H}_{\mathrm{A}^{\prime}}\right), 7.09(\mathrm{~d}, 2 \mathrm{H}$, $\left.\mathrm{J}=8.48 \mathrm{~Hz}, \mathrm{Ar}-\mathrm{H}, \mathrm{H}_{\mathrm{B}}, \mathrm{H}_{\mathrm{B}^{\prime}}\right) .{ }^{13} \mathrm{C} \mathrm{NMR}(100 \mathrm{MHz}) \delta(\mathrm{ppm}): 20.56\left(\mathrm{q},-\mathrm{OCOCH}_{3}\right), 20.67(\mathrm{q},-$ $\left.\mathrm{OCOCH}_{3}\right), 20.94\left(\mathrm{q}, \mathrm{Ar}-\mathrm{CH}_{3}\right), 62.73(\mathrm{t}, \mathrm{C}-6), 65.11(\mathrm{~d}, \mathrm{C}-5), 67.69(\mathrm{~d}, \mathrm{C}-4), 93.35(\mathrm{~d}, \mathrm{C}-1)$, 117.18(d, Ar-CH), 127.25(d, C-2), 129.96(d, C-3), 131.86(s, Ar-C), 154.93(s, Ar-C), 170.15(s, $\left.\mathrm{OCOCH}_{3}\right), 170.60\left(\mathrm{~s},-\mathrm{OCOCH}_{3}\right)$. MS (m/z): 320(M $\left.{ }^{+}\right), 287,258,218,213,184,173,139,128$, 111, 97, 71, 57; HRMS: Observed 320.07048; Calculated 320.12599 for $\mathrm{C}_{17} \mathrm{H}_{20} \mathrm{O}_{6}$. Elemental anlaysis: Observed C 62.99 H 6.50; Calculated C 63.71 H 6.29

4'-Methoxyphenyl 4,6-di-O-acetyl-2,3-dideoxy-a-D-erythro-hex-2-enopyranoside (10a) and $\boldsymbol{\beta}$-anomer (10b). ${ }^{\text {aa, } 9 \mathrm{c}}$ Nature: Gummy colourless solid. $R_{f}: 0.7$ (hexane : EtOAc $=6: 4$ ). IR $\left(\mathrm{CHCl}_{3}\right) \cup\left(\mathrm{cm}^{-1}\right): 2980,1740,1614,1498,1372,1210,1186,1161 ;{ }^{1} \mathrm{H}$ NMR $(200 \mathrm{MHz}) \delta$ (ppm): $1.84\left(\mathrm{~s}, 3 \mathrm{H},-\mathrm{OCOCH}_{3}\right.$, of $\left.\beta\right),\left(2.01\left(\mathrm{~s}, 3 \mathrm{H},-\mathrm{OCOCH}_{3}\right.\right.$ of $\left.\alpha\right), 2.04\left(\mathrm{~s}, 3 \mathrm{H},-\mathrm{OCOCH}_{3}\right.$, of $\left.\beta\right)$, 2.10(s, $3 \mathrm{H},-\mathrm{OCOCH}_{3}$ of $\alpha$ ), 3.77(s, 3H, Ar-OCH $), 4.14-4.29$ (m, 3H, H-5, H-6a, $\mathrm{H}-6_{\mathrm{b}}$ ), 5.02(bs, $1 \mathrm{H}, \mathrm{H}-4$ of $\beta$ ), $5.37(\mathrm{~d}, \mathrm{~J}=9.27 \mathrm{~Hz}, \mathrm{H}-4), 5.56(\mathrm{bs}, 1 \mathrm{H}, \mathrm{H}-1$ of $\alpha), 5.57(\mathrm{bs}, 1 \mathrm{H}, \mathrm{H}-1$ of $\beta), 6.00(\mathrm{bs}$, $2 \mathrm{H}, \mathrm{H}-2, \mathrm{H}-3$ of $\alpha$ ), 6.06(bs, $2 \mathrm{H}, \mathrm{H}-2, \mathrm{H}-3$ of $\beta$ ), $6.82\left(\mathrm{~d}, 2 \mathrm{H}, \mathrm{J}=8.79 \mathrm{~Hz}, \mathrm{Ar}-\mathrm{H}, \mathrm{H}_{\mathrm{A}}, \mathrm{H}_{\mathrm{A}^{\prime}}\right), 7.04(\mathrm{~d}$, $\left.2 \mathrm{H}, \mathrm{J}=8.79 \mathrm{~Hz}, \mathrm{Ar}-\mathrm{H}, \mathrm{H}_{\mathrm{A}}, \mathrm{H}_{\mathrm{B}^{\prime}}\right) .{ }^{13} \mathrm{C} \mathrm{NMR}(50 \mathrm{MHz}) \delta(\mathrm{ppm}): 20.65\left(\mathrm{q},-\mathrm{OCOCH}_{3}\right), 20.88(\mathrm{q},-$ $\left.\mathrm{OCOCH}_{3}\right), 55.60\left(\mathrm{q}, \mathrm{Ar}-\mathrm{OCH}_{3}\right), 62.76(\mathrm{t}, \mathrm{C}-6), 65.12(\mathrm{~d}, \mathrm{C}-5), 67.61(\mathrm{~d}, \mathrm{C}-4), 92.92(\mathrm{~d}, \mathrm{C}-1$ of $\beta)$, 94.00(d, C-1 of $\alpha$ ), 114.50(d, Ar-CH), 118.62(d, Ar-CH), 127.22(d, C-2), 129.62(d, C-3), 151.10(s, Ar-C), 155.20(s, Ar-C), 170.17(s, - $\left.\mathrm{OCOCH}_{3}\right), 170.62\left(\mathrm{~s},-\mathrm{OCOCH}_{3}\right) . \mathrm{MS}(\mathrm{m} / \mathrm{z})$ : 336 $\left(\mathrm{M}^{+}\right)$,203, 161, 147, 105, 91; HRMS: Observed 336.121885; Calculated 336.120905 for $\mathrm{C}_{17} \mathrm{H}_{20} \mathrm{O}_{7}$; Elemental Analysis: Observed C 60.41 H 5.85; Calculated C 60.68 H 5.99

4'-Chlorophenyl 4,6-di-O-acetyl-2,3-dideoxy- $\alpha$-D-erythro-hex-2-enopyranoside (11a) and $\beta$ anomer (11b). ${ }^{9 \mathrm{c}}$ Nature: Gummy colorless solid. $R_{f}: 0.7$ (hexane : EtOAc $=7: 3$ ). IR $\left(\mathrm{CHCl}_{3}\right)$ $v\left(\mathrm{~cm}^{-1}\right): 3020,1737,1594,1484,1459,1366,1312,1091 ;{ }^{1} \mathrm{H}$ NMR $(400 \mathrm{MHz}) \delta(\mathrm{ppm}): 1.86(\mathrm{~s}$, $3 \mathrm{H},-\mathrm{OCOCH}_{3}$, of $\beta$ ), 1.99(s, 3H, $-\mathrm{OCOCH}_{3}$ of $\beta$ ), 2.04(s, $3 \mathrm{H},-\mathrm{OCOCH}_{3}$, of $\alpha$ ), 2.11(s, 3H, $\mathrm{OCOCH}_{3}$, of $\alpha$ ), 4.11-4.29(m, 3H, H-5, H- $6_{\mathrm{a}}, \mathrm{H}-6_{\mathrm{b}}$ ), $5.15\left(\mathrm{bs}, 1 \mathrm{H}, \mathrm{H}-4\right.$ of $\beta$ ), $5.38\left(\mathrm{~d}, \mathrm{~J}_{4,5}=9.76 \mathrm{~Hz}\right.$, $1 \mathrm{H}, \mathrm{H}-4 \alpha$ ), $5.64\left(\mathrm{bs}, 1 \mathrm{H}, \mathrm{H}-1\right.$ of $\alpha$ ), $5.75\left(\mathrm{bs}, 1 \mathrm{H} . \mathrm{H}-1\right.$ of $\beta$ ) $5.99\left(\mathrm{~d}, 1 \mathrm{H}, \mathrm{J}_{2,3}=10.25 \mathrm{~Hz}, 1 \mathrm{H}, \mathrm{H}-3\right)$, $6.03\left(\mathrm{~d}, \mathrm{~J}_{2,3}=10.75 \mathrm{~Hz}, 1 \mathrm{H}, \mathrm{H}-2\right), 7.04\left(\mathrm{~d}, \mathrm{~J}=9.27 \mathrm{~Hz}, 2 \mathrm{H}, \mathrm{Ar}-\mathrm{H}, \mathrm{H}_{\mathrm{A}}, \mathrm{H}_{\mathrm{A}^{\prime}}\right), 7.25(\mathrm{~d}, 2 \mathrm{H}, \mathrm{J}=9.27 \mathrm{~Hz}$, $\left.\mathrm{Ar}-\mathrm{H}, \mathrm{H}_{\mathrm{B}}, \mathrm{H}_{\mathrm{B}}\right) .{ }^{13} \mathrm{C} \mathrm{NMR}(100 \mathrm{MHz}) \delta(\mathrm{ppm}): 21.01\left(\mathrm{q},-\mathrm{OCOCH}_{3}\right), 21.27\left(\mathrm{q},-\mathrm{OCOCH}_{3}\right), 62.94(\mathrm{t}$, 
C-6), 65.15(d, C-5), 68.10(d, C-4), 93.04(d, C-1 of $\alpha), 91.53(\mathrm{~d}, \mathrm{C}-1$ of $\beta), 118.14(\mathrm{~d}, \mathrm{Ar}-\mathrm{CH})$, 126.60(d, Ar-CH), 127.33(s, Ar-C), 129.42(d, Ar-CH), 130.42(d, Ar-CH), 155.65(s, Ar-C), 170.37(s, $\left.-\mathrm{OCOCH}_{3}\right), 170.76\left(\mathrm{~s},-\mathrm{OCOCH}_{3}\right)$. MS (m/z): 356(M $\left.{ }^{+}\right), 213,153,111,81$; HRMS: Observed 305.1012985; Calculated 305.102515 for $\mathrm{C}_{16} \mathrm{H}_{17} \mathrm{O}_{6} \mathrm{Cl}(-\mathrm{cl})$.

Methyl 6-O-[4',6'-di-O-acetyl-2',3'-dideoxy-D-erythro-hex-2'-enopyranosyl]-2,3,4-tri-Omethyl- $\alpha$-D-glucopyranoside $\left(\mathbf{1 3}^{\mathbf{a}}\right)$ and $\boldsymbol{\beta}$-anomer (13b). Nature: Viscous liquid. $R_{f}$ : 0.4 (hexane : EtOAc $=5: 5)$. IR $\left(\mathrm{CHCl}_{3}\right) \cup\left(\mathrm{cm}^{-1}\right): 3008,2912,2848,1737,1596,1539,1491,1462$, 1369, 1260, 1148, 1100, 1049, 992, 899, 816; ${ }^{1} \mathrm{H}$ NMR (400 MHz) $\delta$ (ppm): 2.09(s, 3H, $\left.\mathrm{OCOCH}_{3}\right), 2.11\left(\mathrm{~s}, 3 \mathrm{H},-\mathrm{OCOCH}_{3}\right), 3.18-4.28(\mathrm{~m}, 9 \mathrm{H}, \mathrm{H}-2, \mathrm{H}-3, \mathrm{H}-4, \mathrm{H}-5, \mathrm{H}-6 \mathrm{a}, \mathrm{H}-6 \mathrm{~b}, \mathrm{H}-5$ ', H6'a, H-6'b), 3.40(s, 3H, $\left.-\mathrm{OCH}_{3}\right), 3.54\left(\mathrm{~s}, 3 \mathrm{H},-\mathrm{OCH}_{3}\right), 3.62\left(\mathrm{~s}, 3 \mathrm{H},-\mathrm{OCH}_{3}\right), 3.68\left(\mathrm{~s}, 3 \mathrm{H},-\mathrm{OCH}_{3}\right)$, $4.81\left(\mathrm{~d}, \mathrm{~J}_{1,2}=3.42 \mathrm{~Hz}, 1 \mathrm{H}, \mathrm{H}-1\right), 5.13\left(\mathrm{bs}, 1 \mathrm{H}, \mathrm{H}-1^{\prime}\right), 5.20-5.21\left(\mathrm{~m}, 2 \mathrm{H}, \mathrm{H}-4^{\prime}, \mathrm{H}-1^{\prime}\right.$ of $\left.\beta\right), 5.32\left(\mathrm{~d}, \mathrm{~J}_{4^{\prime}, 5^{\prime}}\right.$ $\left.=9.76 \mathrm{~Hz}, \mathrm{H}-4^{\prime}\right), 5.88\left(\mathrm{bs}, 2 \mathrm{H}, \mathrm{H}-2^{\prime}, \mathrm{H}-3^{\prime}\right.$ of $\left.\alpha\right), 5.97\left(\mathrm{bs}, 2 \mathrm{H}, \mathrm{H}-2^{\prime}, \mathrm{H}-3\right.$ ', of $\left.\beta\right) .{ }^{13} \mathrm{C} \mathrm{NMR}(100 \mathrm{MHz})$ $\delta(\mathrm{ppm}):$ 20.81(q, $\left.-\mathrm{OCOCH}_{3}\right), 20.99\left(\mathrm{q},-\mathrm{OCOCH}_{3}\right), 55.15\left(\mathrm{q},-\mathrm{OCH}_{3}\right), 58.97\left(\mathrm{q},-\mathrm{OCH}_{3}\right), 60.39(\mathrm{q}$, $\left.-\mathrm{OCH}_{3}\right), 60.88\left(\mathrm{q},-\mathrm{OCH}_{3}\right), 62.85(\mathrm{t}, \mathrm{C}-6$ ' of $\alpha), 63.43(\mathrm{t}, \mathrm{C}-6 \mathrm{\prime}$ of $\beta), 65.19(\mathrm{~d}), 66.83(\mathrm{~d}), 66.98(\mathrm{t}, \mathrm{C}-$ 6), 69.74(d), 79.14(d), 81.76(d), 83.54(d), 94.64(d, C-1), 97.38(d, C-1'), 127.68(d, C-2'), 129.08(d, C-2'), 170.29(s, $\left.-\mathrm{OCOCH}_{3}\right), 170.82\left(\mathrm{~d},-\mathrm{OCOCH}_{3}\right) . \mathrm{MS}(\mathrm{m} / \mathrm{z}): 448,392,331,301,274$, 246, 232, 189, 161, 147, 119, 105, 91, 57; HRMS: Observed 448.192065; Calculated 448.194465 for $\mathrm{C}_{20} \mathrm{H}_{32} \mathrm{O}_{11}$.

2-(1',5'-Anhydro-4',6'-di-O-acetyl-2',3'-dideoxy-a-D-erythro-hex-2'-enopyranosyl)-4methylphenol (14a) and $\boldsymbol{\beta}$-anomer (14b). ${ }^{9 \mathrm{a}}$ Nature: Gummy solid. $R_{f}: 0.4$ (hexane : EtOAc $=7$ : 3 ). IR $\left(\mathrm{CHCl}_{3}\right)$ v $\left(\mathrm{cm}^{-1}\right): 3440,2928,2864,1731,1641,1600,1491,1452,1369,1289,1072$, 972, 889, 825, 640; ${ }^{1} \mathrm{H}$ NMR (400 MHz) $\delta(\mathrm{ppm}): 2.08\left(\mathrm{~s}, 3 \mathrm{H},-\mathrm{OCOCH}_{3}\right.$, of $\left.\beta\right), 2.09(\mathrm{~s}, 3 \mathrm{H}$, $\mathrm{OCOCH}_{3}$ of $\left.\beta\right), 2.11\left(\mathrm{~s}, 6 \mathrm{H}, 2 \mathrm{x}-\mathrm{OCOCH}_{3}\right.$, of $\left.\alpha\right), 2.25\left(\mathrm{~s}, 3 \mathrm{H},-\mathrm{ArCH}_{3}\right.$ of $\left.\alpha\right), 2.26\left(\mathrm{~s}, 3 \mathrm{H},-\mathrm{ArCH}_{3}\right.$ of $\beta$ ), 3.90-4.35(m, 3H, H'-5, H-6'a, H-6'b), 5.25(dd, $\mathrm{J}_{4^{\prime}, 5^{\prime}}=6.62 \mathrm{~Hz}, \mathrm{~J}_{3^{\prime}, 4^{\prime}}=3.32 \mathrm{~Hz}, 1 \mathrm{H}, \mathrm{H}-4^{\prime}$ of $\alpha$ ), $5.45\left(\mathrm{dd}, \mathrm{J}_{1^{\prime}, 2^{\prime}}=3.50 \mathrm{~Hz}, \mathrm{~J}_{1^{\prime}, 3^{\prime}}=2.13 \mathrm{~Hz}, 1 \mathrm{H}, \mathrm{H}-1^{\prime}\right.$ of $\left.\beta\right), 5.47\left(\mathrm{bs}, 1 \mathrm{H}, \mathrm{H}-1^{\prime}\right.$ of $\left.\alpha\right), 5.49\left(\mathrm{ddd}, \mathrm{J}_{4^{\prime}, 5^{\prime}}=\right.$ $8.81 \mathrm{~Hz}, \mathrm{~J}_{3^{\prime}, 4^{\prime}}=1.84 \mathrm{~Hz}, \mathrm{~J}_{2^{\prime}, 4^{\prime}}=1.27 \mathrm{~Hz}, 1 \mathrm{H}, \mathrm{H}-4^{\prime}$ of $\left.\beta\right), 5.82\left(\mathrm{dd}, \mathrm{J}_{2^{\prime}, 3^{\prime}}=10.14 \mathrm{~Hz}, \mathrm{~J}_{3^{\prime}, 4^{\prime}}=1.74 \mathrm{~Hz}, 1 \mathrm{H}\right.$, $\mathrm{H}-3^{\prime}$ of $\left.\beta\right), 5.98\left(\mathrm{dd}, \mathrm{J}_{2^{\prime}, 3^{\prime}}=10.42 \mathrm{~Hz}, \mathrm{~J}_{3^{\prime}, 4^{\prime}}=2.01 \mathrm{~Hz}, 1 \mathrm{H}, \mathrm{H}-2^{\prime}\right.$ of $\left.\beta\right), 6.04\left(\mathrm{dd}, \mathrm{J}_{2^{\prime}, 3^{\prime}}=10.89 \mathrm{~Hz}, \mathrm{~J}_{3^{\prime}, 4^{\prime}}=\right.$ $2.01 \mathrm{~Hz}, 1 \mathrm{H}, \mathrm{H}-3^{\prime}$ of $\left.\alpha\right), 6.28\left(\mathrm{ddd}, \mathrm{J}_{2^{\prime}, 3^{\prime}}=10.39 \mathrm{~Hz}, \mathrm{~J}_{3^{\prime}, 4^{\prime}}=2.99 \mathrm{~Hz}, \mathrm{~J}_{2^{\prime}, 4^{\prime \prime}}=1.28 \mathrm{~Hz}, 1 \mathrm{H}, \mathrm{H}-2^{\prime}\right.$ of $\alpha$ ), $6.76\left(\mathrm{~d}, \mathrm{~J}_{5,6}=8.18 \mathrm{~Hz}, 1 \mathrm{H}, \mathrm{H}-6\right.$ of $\left.\alpha\right), 6.79-7.10(\mathrm{~m}, 4 \mathrm{H}, \mathrm{Ar}-\mathrm{H}, \mathrm{Ar}-\mathrm{OH}) .{ }^{13} \mathrm{C} \mathrm{NMR}(100 \mathrm{MHz}) \delta$ (ppm): 20.46(q, $\left.-\mathrm{OCOCH}_{3}\right), 20.53\left(\mathrm{q},-\mathrm{OCOCH}_{3}\right), 20.76\left(\mathrm{q}, \mathrm{Ar}-\mathrm{CH}_{3}\right.$ of $\alpha$ ), 21.00(q, $\mathrm{Ar}-\mathrm{CH}_{3}$ of $\beta$ ), 62.17(t, C-6' of $\alpha), 62.90(\mathrm{t}, \mathrm{C}-6$ ' of $\beta), 64.58\left(\mathrm{~d}, \mathrm{C}-4^{\prime}\right.$ of $\left.\beta\right), 64.92\left(\mathrm{~d}, \mathrm{C}-44^{\prime}\right.$ of $\left.\alpha\right), 70.68\left(\mathrm{~d}, \mathrm{C}-5^{\prime}\right.$ of $\alpha), 72.37\left(\mathrm{~d}, \mathrm{C}-5^{\prime}\right.$ of $\left.\beta\right), 74.75\left(\mathrm{~d}, \mathrm{C}-1^{\prime}\right.$ of $\left.\alpha\right), 76.71\left(\mathrm{~d}, \mathrm{C}-1^{\prime}\right.$ of $\left.\beta\right), 116.95(\mathrm{~d}, \mathrm{Ar}-\mathrm{CH}$ of $\alpha), 117.15(\mathrm{~d}$, Ar-CH of $\beta$ ), 123.37(d), 124.83(d), 124.86(d), 127.71(d), 129.11(d), 129.21(s, s, Ar-C of $\alpha$ ), 129.50(s, s, Ar-C of $\beta$ ), 130.14(d), 130.67(d), 130.90(d), 131.39(d), 152.77(s, Ar-C of $\alpha)$, 153.55(s, Ar-C of $\beta), 170.24\left(\mathrm{~s},-\mathrm{OCOCH}_{3}\right), 170.88\left(\mathrm{~s},-\mathrm{OCOCH}_{3}\right) . \mathrm{MS}(\mathrm{m} / \mathrm{z}): 320\left(\mathrm{M}^{+}\right), 262,187$, 161, 145, 135; HRMS: Observed 320.12006; Calculated 320.12599 for ${ }_{17} \mathrm{H}_{20} \mathrm{O}_{6}$

2-(1',5'-Anhydro-4',6'-di-O-acetyl-2',3'- dideoxy- $\alpha-D-\quad$ erythro-hex-2'- enopyranosyl)-4 methoxyphenol (15a) and $\boldsymbol{\beta}$-anomer (15b). ${ }^{\text {a }}$ Nature: Viscous liquid. $R_{f}: 0.4$ (hexane : EtOAc $=$ 7 : 3). IR $\left(\mathrm{CHCl}_{3}\right) \cup\left(\mathrm{cm}^{-1}\right): 3450,2928,2860,1737,1638,1604,1456,1372,1280,1084 ;{ }^{1} \mathrm{H}$ NMR $(400 \mathrm{MHz}) \delta(\mathrm{ppm}): 2.082\left(\mathrm{~s}, 3 \mathrm{H},-\mathrm{OCOCH}_{3}\right.$ of $\left.\alpha\right), 2.089\left(\mathrm{~s}, 3 \mathrm{H},-\mathrm{OCOCH}_{3}\right.$ of $\left.\alpha\right), 2.11(\mathrm{~s}$, 
$6 \mathrm{H}, 2 \times-\mathrm{OCOCH}_{3}$, of $\left.\beta\right), 3.74\left(\mathrm{~s}, 3 \mathrm{H},-\mathrm{ArOCH}_{3}\right.$ of $\left.\beta\right), 2.26\left(\mathrm{~s}, 3 \mathrm{H},-\mathrm{ArCH}_{3}\right.$ of $\left.\alpha\right), 3.88-4.00(\mathrm{~m}, \mathrm{H}-$ $5^{\prime}$ of $\alpha, \mathrm{H}-5^{\prime}$ of $\beta$ ), 4.10-4.35(m, H-6'a, H-6'b of $\alpha, \mathrm{H}-6$ 'a, H-6'b of $\beta$ ), 5.26(ddd, $\mathrm{J}_{4^{\prime}, 5^{\prime}}=6.85 \mathrm{~Hz}$, $\mathrm{J}_{3^{\prime}, 4^{\prime}}=3.75 \mathrm{~Hz}, \mathrm{~J}_{2^{\prime}, 4^{\prime}}=1.49 \mathrm{~Hz}, 1 \mathrm{H}, \mathrm{H}-4^{\prime}$ of $\left.\alpha\right), 5.43-5.52\left(\mathrm{~m}, 3 \mathrm{H}, \mathrm{H}-1^{\prime}\right.$ of $\beta, \mathrm{H}^{\prime} 1^{\prime}$ of $\alpha, \mathrm{H}-4^{\prime}$ of $\left.\beta\right)$, $5.83\left(\mathrm{dd}, \mathrm{J}_{2^{\prime}, 3^{\prime}}=10.33 \mathrm{~Hz}, \mathrm{~J}_{3^{\prime}, 4^{\prime}}=1.73 \mathrm{~Hz}, 1 \mathrm{H}, \mathrm{H}-3^{\prime}\right.$ of $\left.\beta\right), 5.95-6.07\left(\mathrm{~m}, 2 \mathrm{H}, \mathrm{H}-2^{\prime}\right.$ of $\beta, \mathrm{H}-3^{\prime}$ of $\left.\alpha\right)$, $6.24\left(\mathrm{ddd}, \mathrm{J}_{2^{\prime}, 3^{\prime}}=10.36 \mathrm{~Hz}, \mathrm{~J}_{1^{\prime}, 2^{\prime \prime}}=3.04 \mathrm{~Hz}, \mathrm{~J}_{2^{\prime}, 4^{\prime}}=1.27 \mathrm{~Hz}, 1 \mathrm{H}, \mathrm{H}-2^{\prime}\right.$ of $\left.\alpha\right), 6.65-6.89(\mathrm{~m}, 4 \mathrm{H}, \mathrm{Ar}-\mathrm{H}$, Ar-OH). ${ }^{13} \mathrm{C}$ NMR $(100 \mathrm{MHz}) \delta(\mathrm{ppm}): 20.66\left(\mathrm{q},-\mathrm{OCOCH}_{3}\right), 20.91\left(\mathrm{q},-\mathrm{OCOCH}_{3}\right), 55.74(\mathrm{q}, \mathrm{Ar}-$ $\left.\mathrm{OCH}_{3}\right), 62.19\left(\mathrm{t}, \mathrm{C}-66^{\prime}\right.$ of $\left.\alpha\right), 62.89\left(\mathrm{t}, \mathrm{C}-6{ }^{\prime}\right.$ of $\left.\beta\right), 64.59\left(\mathrm{~d}, \mathrm{C}-4^{\prime}\right.$ of $\left.\beta\right), 64.86\left(\mathrm{~d}, \mathrm{C}-4^{\prime}\right.$ of $\left.\alpha\right), 70.63(\mathrm{~d}$, C-5' of $\alpha), 72.03(d, C-5$ ' of $\beta), 74.73(d, C-1$ ' of $\alpha), 76.36(d, C-1$ ' of $\beta), 112.83(d), 114.59(d)$, 114.79(d), 117.61(d), 117.80(d), 124.59(d), 124.94(d), 125.17(d), 130.47(d), 131.11(d), 148.71(s, Ar-C of $\alpha$ ), 149.55(s, Ar-C of $\beta$ ), 152.98(s, Ar-C of $\alpha$ ), 153.26(s, Ar-C of $\beta$ ), 170.17(s, $\left.-\mathrm{OCOCH}_{3}\right), 170.80\left(\mathrm{~s},-\mathrm{OCOCH}_{3}\right)$. MS (m/z): 336M $\left.\mathrm{M}^{+}\right)$, 276, 216. 203, 161, 105, 91; HRMS: Observed 336.117857; Calculated 336.120905 for $\mathrm{C}_{17} \mathrm{H}_{20} \mathrm{O}_{7}$

\section{2-(1',5'-Anhydro-4'-O-acetyl-2',3',6'-trideoxy-L-threo-hex-2'-enopyranosyl)-4methylphenol}

(17a) and $\beta$-anomer (17b). Nature: Viscous liquid. $R_{f}: 0.4$ (hexane : EtOAc $\left.=8: 2\right)$. IR $\left(\mathrm{CHCl}_{3}\right)$ $v\left(\mathrm{~cm}^{-1}\right): 3450,2980,1740,1640.1598,1438,1362,1257 ;{ }^{1} \mathrm{H}$ NMR $(200 \mathrm{MHz}): \delta(\mathrm{ppm}): 1.31(\mathrm{~d}$, $\mathrm{J}=4.85 \mathrm{~Hz}, 3 \mathrm{H}, 6^{\prime}-\mathrm{CH}_{3}$ of $\left.\alpha\right), 1.34\left(\mathrm{~d}, \mathrm{~J}=4.85 \mathrm{~Hz}, 3 \mathrm{H}, 6^{\prime}-\mathrm{CH}_{3}\right.$ of $\left.\beta\right), 2.04\left(\mathrm{~s}, 3 \mathrm{H},-\mathrm{OCOCH}_{3}\right.$, of $\alpha$ ), $2.10\left(\mathrm{~s}, 3 \mathrm{H},-\mathrm{OCOCH}_{3}\right.$ of $\left.\beta\right), 2.24\left(\mathrm{~s}, 3 \mathrm{H},-\mathrm{ArCH}_{3}\right.$ of $\left.\alpha\right), 2.25\left(\mathrm{~s}, 3 \mathrm{H},-\mathrm{ArCH}_{3}\right.$ of $\left.\beta\right), 3.62-3.90(\mathrm{~m}$, $1 \mathrm{H}, \mathrm{H}-5^{\prime}$ of $\beta$ ), 3.98-4.10(m, 1H, H-5' of $\left.\alpha\right), 4.55-5.40\left(\mathrm{~m}, 4 \mathrm{H}, \mathrm{H}-1^{\prime}\right.$ of $\alpha, \mathrm{H}-1^{\prime}$ of $\beta, \mathrm{H}^{-4}$ ' of $\alpha, \mathrm{H}-4^{\prime}$ of $\beta), 5.79\left(\mathrm{dd}, \mathrm{J}_{2^{\prime}, 3^{\prime}}=10.25 \mathrm{~Hz}, \mathrm{~J}_{3^{\prime}, 4^{\prime}}=2.05 \mathrm{~Hz}, 1 \mathrm{H}, \mathrm{H}-3^{\prime}\right.$ of $\left.\beta\right), 5.86-6.02\left(\mathrm{~m}, 2 \mathrm{H}, \mathrm{H}-2^{\prime}\right.$ of $\beta, \mathrm{H}-3^{\prime}$ of $\alpha), 6.13\left(\mathrm{dd}, \mathrm{J}_{2^{\prime}, 3^{\prime}}=10.25 \mathrm{~Hz}, \mathrm{~J}_{1^{\prime}, 2^{\prime \prime}}=1.86 \mathrm{~Hz}, 1 \mathrm{H}, \mathrm{H}-2^{\prime}\right.$ of $\left.\alpha\right), 6.69-6.91(\mathrm{~m}, 4 \mathrm{H}, \mathrm{Ar}-\mathrm{H}, \mathrm{Ar}-\mathrm{OH}) .{ }^{13} \mathrm{C}$ $\operatorname{NMR}(50 \mathrm{MHz}) \delta(\mathrm{ppm}): 16.06\left(\mathrm{q}, \mathrm{C}-6{ }^{\prime}\right.$ of $\left.\alpha\right), 18.74(\mathrm{q}, \mathrm{C}-6$ ' of $\beta), 20.40\left(\mathrm{q},-\mathrm{OCOCH}_{3}\right), 21.01(\mathrm{q},-$ $\left.\mathrm{ArCH}_{3}\right), 67.77(\mathrm{~d}), 68.83(\mathrm{~d}), 70.04(\mathrm{~d}), 70.46(\mathrm{~d}), 71.98(\mathrm{~d}), 73.68\left(\mathrm{~d}, \mathrm{C}-1^{\prime}\right.$ of $\left.\alpha\right), 76.36(\mathrm{~d}, \mathrm{C}-1$ ' of $\beta)$, 115.06(d), 116.89(d), 123.46(d), 125.44(d), 127.84(d), 128.83(d), 129.05(d), 129.33(s, Ar-C), 129.96(s, Ar-C), 130. 29(d), 130.44(d), 131.57(d), 132.02(d), 152.80(s, Ar-C), 153.57(s, Ar-C), $170.42\left(\mathrm{~s},-\mathrm{OCOCH}_{3}\right.$ of $\left.\alpha\right), 170.54\left(\mathrm{~s},-\mathrm{OCOCH}_{3}\right.$ of $\left.\beta\right)$.

\section{2-(1',5'-Anhydro-4'-O-acetyl-2',3',6'-trideoxy-L-threo-hex-2'-enopyranosyl)-4}

methoxyphenol (18a) and $\boldsymbol{\beta}$-anomer (18b). Nature: Viscous liquid. $R_{f}: 0.4$ (hexane : EtOAc $=$ 6: 4). IR $\left(\mathrm{CHCl}_{3}\right)$ v $\left(\mathrm{cm}^{-1}\right): 3452,2987,1737,1638,1602,1439,1364,1237 ;{ }^{1} \mathrm{H}$ NMR $(200 \mathrm{MHz}) \delta(\mathrm{ppm}): 1.31\left(\mathrm{~d}, \mathrm{~J}=5.16 \mathrm{~Hz}, 3 \mathrm{H}, 6^{\prime}-\mathrm{CH}_{3}\right.$ of $\left.\alpha\right), 1.35\left(\mathrm{~d}, \mathrm{~J}=4.85 \mathrm{~Hz}, 3 \mathrm{H}, 6{ }^{\prime}-\mathrm{CH}_{3}\right.$ of $\beta$ ), $2.10\left(\mathrm{~s}, 3 \mathrm{H},-\mathrm{OCOCH}_{3}\right.$, of $\left.\beta\right), 2.11\left(\mathrm{~s}, 3 \mathrm{H},-\mathrm{OCOCH}_{3}\right.$ of $\left.\alpha\right), 3.74\left(\mathrm{~s}, 3 \mathrm{H},-\mathrm{ArOCH}_{3}\right.$ of $\left.\alpha\right), 3.75(\mathrm{~s}, 3 \mathrm{H}$, $-\mathrm{ArCH}_{3}$ of $\beta$ ), 3.80-3.90(m, $1 \mathrm{H}, \mathrm{H}-5^{\prime}$ of $\beta$ ), 4.05(apparent qt, $\mathrm{J}=6.52 \mathrm{~Hz}, 1 \mathrm{H}, \mathrm{H}-5^{\prime}$ of $\alpha$ ), 5.01(bs, $1 \mathrm{H}, \mathrm{H}-44^{\prime}$ of $\left.\beta\right), 5.22\left(\mathrm{dd}, \mathrm{J}_{4^{\prime}, 5^{\prime}}=8.75 \mathrm{~Hz}, \mathrm{~J}_{2^{\prime}, 4^{\prime}}=1.36 \mathrm{~Hz}, 1 \mathrm{H}, \mathrm{H}-4^{\prime}\right.$ of $\left.\alpha\right), 5.32\left(\mathrm{~d}, \mathrm{~J}_{1^{\prime}, 2^{\prime}}=1.94 \mathrm{~Hz}, 1 \mathrm{H}\right.$, $\mathrm{H}-1^{\prime}$ of $\left.\beta\right), 5.35\left(\mathrm{bs}, \mathrm{H}-1^{\prime}\right.$ of $\left.\alpha\right), 5.81\left(\mathrm{dd}, \mathrm{J}_{2^{\prime}, 3^{\prime}}=10.29 \mathrm{~Hz}, \mathrm{~J}_{3^{\prime}, 4^{\prime}}=2.10 \mathrm{~Hz}, 1 \mathrm{H}, \mathrm{H}-3^{\prime}\right.$ of $\left.\beta\right), 5.85-$ $6.04\left(\mathrm{~m}, 2 \mathrm{H}, \mathrm{H}-2^{\prime}\right.$ of $\beta, \mathrm{H}-3^{\prime}$ of $\left.\alpha\right), 6.13\left(\mathrm{dd}, \mathrm{J}_{2^{\prime}, 3^{\prime}}=10.34 \mathrm{~Hz}, \mathrm{~J}_{3^{\prime}, 4^{\prime}}=2.29 \mathrm{~Hz}, 1 \mathrm{H}, \mathrm{H}-2^{\prime}\right.$ of $\left.\alpha\right)$, 6.636.93(m, 4H, Ar-H, Ar-OH). ${ }^{13} \mathrm{C}$ NMR (50 MHz) $\delta(\mathrm{ppm}): 16.13(\mathrm{q}, \mathrm{C}-6$ ' of $\alpha), 18.45\left(\mathrm{q}, \mathrm{C}-6^{\prime}\right.$ of $\beta), 21.02\left(\mathrm{q},-\mathrm{OCOCH}_{3}\right), 55.78\left(\mathrm{q},-\mathrm{Ar}-\mathrm{OCH}_{3}\right), 68.76(\mathrm{~d}), 70.03(\mathrm{~d}), 70.36(\mathrm{~d}), 71.86(\mathrm{~d}), 73.65(\mathrm{~d}, \mathrm{C}-$ $1^{\prime}$ of $\left.\alpha\right), 76.36(d, C-1$ ' of $\beta), 113.00(d), 114.34(d), 114.58(d), 117.60(d), 117.69(d), 123.33(d)$, 124.48(d), 124.86(d), 125.64(d), 131.22(d), 131.58(d), 148.89(s, Ar-C), 149.69(s, Ar-C), 153.25(s, Ar-C), 170.40(s, $\left.-\mathrm{OCOCH}_{3}\right) . \mathrm{MS}(\mathrm{m} / \mathrm{z}): 278\left(\mathrm{M}^{+}\right), 218,192,161,124,91$ 
2-(D-Glycero-1',2'-dihydroxyethyl)furan (21). ${ }^{19}$ Nature: Viscous liquid. $R_{f}: 0.6$ (hexane : EtOAc $=7: 3) .[\alpha]_{\mathrm{D}}=+34.5^{\circ}\left(\mathrm{c} 2.4, \mathrm{CHCl}_{3}\right)$. IR $\left(\mathrm{CHCl}_{3}\right) \cup\left(\mathrm{cm}^{-1}\right): 3600,3424,2928,1600$, 1494, 1468, 1376, 1145, 1088, 1068, 998, 937, 873, 825, 652, 595; ${ }^{1} \mathrm{H}$ NMR (200 MHz) $\delta$

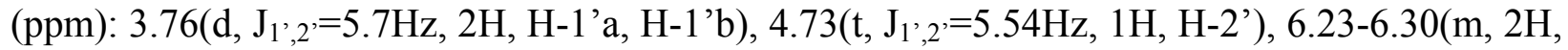
$\mathrm{H}-3, \mathrm{H}-4), 7.32-7.33(\mathrm{~m}, 1 \mathrm{H}, \mathrm{H}-5) ;{ }^{13} \mathrm{C} \mathrm{NMR}\left(50 \mathrm{MHz}, \mathrm{CDCl}_{3}, \delta\right)$ 64.83(t, C-1'), 68.22(d, C-2'), 106.78(d, C-5), 110.17(d, C-3), 142.07(d, C-4), 153.58(s, C-2). MS (m/z): 128( $\left.\mathrm{M}^{+}\right), 97,85,83$, 69, 47, 41; HRMS: Observed 128.0502322; Calculated 128.047345 for $\mathrm{C}_{6} \mathrm{H}_{8} \mathrm{O}_{3}$.

\section{Acknowledgments}

The authors thank: Department of Science and Technology, India, for financial support, and RSIC, IIT, Chennai, SPIC Science Foundation, Chennai and Sun Pharmaceutical Advanced Research Center, Baroda for spectral data. One of us (BSB) also thanks Dr. K. Vijayakumaran, Director, R\&D, Chimique Laboratories, Chennai, for useful discussions.

\section{References}

1. (a) Ferrier, R. J.; Overend, W. G.; Ryan, A. E. J. Chem. Soc. C 1962, 3667. (b) Ferrier, R. J.; Overend, W. G.; Ryan, A. E. J. Chem. Soc. C 1964, 5443. (c) Ferrier, R. J.; Prasad, N. J. Chem. Soc. C. 1969, 570. (d) Grynkiwiez G.; Priebe, W; Zamojski, A. Carbohydr. Res. 1979, 68, 33. (e) Ferrier, R.J. Topics in Current Chemistry 2001, 215, 153.

2. (a) Levy, D. E.; Tang, C. The Chemistry of C-glycosides; Pergamon Press: Tarrytown, NY, 1995. (b) Ferrier, R. J.; Zubkov, O. A. Org. React. 2003, 62, 569.

3. Lopez, J. C.; Gomez, A. M.; Valverde, S.; Fraser-Reid, B. J. Org. Chem. 1995, 60, 3851.

4. (a) Toshima, K.; Tatsuta, K. Chem. Rev. 1993, 93, 1503. (b) Toshima, K; Ishizuka, T; Matsuo, G; Nakata, M; Kinoshito, M. J. Chem. Soc., Chem. Commun. 1993, 704.

5. Mereyala, H. B.; Venkataramanaiah, K. C. J. Chem. Res (S). 1991, 197.

6. (a) Toshima, K.; Ishizuka, T.; Matsuo, G.; Nakata, M. Synlett 1995, 306. (b) Toshima, K.; Ishizuka, T.; Matsuo, G.; Nakata, M. J. Chem. Soc. Chem. Commun. 1995, 306. (c) Toshima, K.; Miyamoto, N.; Matsuo, G.; Nakata, M.; Matsumura, S. J. Chem. Soc., Chem. Commun. 1996, 1379.

7. Bhagavathy, S.; Bose, A. K.; Balasubramanian, K. K. Tetrahedron Lett. 2002, 43, 6795.

8. Kim, H.; Men, H.; Lee, C. J. Am. Chem. Soc. 2004, 126, 1336, references cited there in.

9. (a) Ramesh, N. G; Balasubramanian, K. K. Tetrahedron Lett. 1992, 33, 3061. (b) Booma, C.; Balasubramanian, K. K. J. Chem. Soc., Chem. Commun. 1993, 1394. (c) Ramesh, N. G; Ph. D. dissertation, Indian Institute of Technology Madras, Chennai, India, 1993.

10. (a) Boga, S. B.; Balasubramanian, K. K. "'LPDE induced Ferrier reaction -Synthesis of 2,3unsaturated-C-aryl glycosides" XVIII ${ }^{\text {th }}$ International Carbohydrate Symposium; Milan, 
Italy, July 21-26, 1996. (b) Boga, S. B.; Balasubramanian, K. K. Behaviour of Ferrier systems in LPDE medium: Synthesis of 2-deoxy-galactosides; $9^{\text {th }}$ European Carbohydrate Symposium, Utrecht, Netherlands, July 6-11, 1997. (c) Boga, S. B.; Balasubramanian, K. K. Carbohydrate Lett. 1999, 3, 339.

11. (a) Boga, S. B.; Balasubramanian, K. K. Lithium tetrafluoroborate catalyzed Ferrier rearrangement of tri-O-acetyl-D-galactal - Facile synthesis of alky 2,3-unsaturated glycopyranosid; $215^{\text {th }}$ American Chemical Society Meeting, Dallas, USA, March 29 to April 2, 1998. (b) Boga, S. B.; Balasubramanian, K. K. Syn. Commun. 1999, 29, 4299. (c) Boga, S. B.; Balasubramanian, K. K. Tetrahedron Lett. 1999, 40, 5777. (d) Boga, S. B.; Balasubramanian, K. K. Lithium tetrafluoroborate in organic synthesis-Some recent developments ; Acros Organics Acta 1999, 7, 1.

12. (a) Li, C. J.; Chan, T-H. Tetrahedron 1999, 55, 11149. (b) Babu, G.; Perumal, P. T. Aldrichima Acta. 2000, 33, 16. Ghosh, R. Indian. J. Chem. 2001, 40B, 550.

13. (a) Boga, S. B.; Balasubramanian, K. K. "Synthesis of alkyl and aryl 2,3-unsaturated glucopyranosides - Catalyzed by indium trichloride', $218^{\text {th }}$ American Chemical Society Meeting, New Orleans, USA, August 22-26, 1999. (b) Boga, S. B.; Balasubramanian, K. K. Tetrahedron Lett. 2000, 41, 1271.

14. (a) Yadav, J. S.; Reddy, B. V. S.; Raman, J. V.; Niranjan, N.; Kumar, S. K.; Kunwar, A. C. Tetrahedron Lett. 2002, 43, 2095. (b) Das, S. K.; Reddy, K. A.; Roy, J. Synlett., 2003, 11, 1607 and references cited there in. (c) Das, S. K.; Reddy, K. A.; Abbineni, C.; Roy, J.; Rao, K. V. L. N.; Sacwani, R. H.; Iqbal, J. Tetrahedron Lett. 2003, 44, 4507.

15. (a) Roth, W.; Pigman, W. D-glucal and the glycals in Whistler, R. L.; Wolform, M. L.; Bemiller, J. N. Methods in Carbohydr. Chem. Academic Press, New York. 1963, II, 405; (b) Rosenthal, A.; Read, D. The oxo reaction in carbohydrate chemistry In Whistler, R. L.; Wolform, M. L.; Bemiller, J. N., Eds; Methods in Carbohydr. Chem. Academic Press: New York, 1963, II, 457.

16. Dearg, S. B.; Steven, V. L.; Sadie, V.; Mervyn, T. Tetrahedron 1991, 50, 5369.

17. Moufid, N.; Chapleur, Y.; Mayon, P. J. Chem. Soc., Perkin Trans.1 1992, 999.

18. (a) Butz, T; Sauer, J; Tetrahedron: Asymmetry 1977, 8, 703. (b) Hauserl, F.M; Ellenberger, S.R; Ellenberberger, W. P. Tetrahedron Lett. 1988, 29, 4939. (c) Taniguchi; Nakamura, T. K; Ogasawara, K. Synlett 1996, 971. (d) Harris, J. M; Keranen, M. D; O’Doherty, G. A. J. Org Chem. 1999, 64, 2982. (e) Babu, B. S.; Balasubramanian, K. K. Chemistry of Glycols; $8^{\text {th }}$ National Organic Symposium Trends (NOST), Jaipur, India. March 2-5, 2000. (f) Babu, B. S.; Balasubramanian, K. K. J. Org. Chem. 2000, 65, 4198. (g) Agarwal, A.; Rani, S.; Vankar, Y. D. J. Org. Chem. 2004, 69, 6137.

19. Hayashi, M.; Kawabata, H.; Yamada, K. Chem. Comm. 1999, 965. 